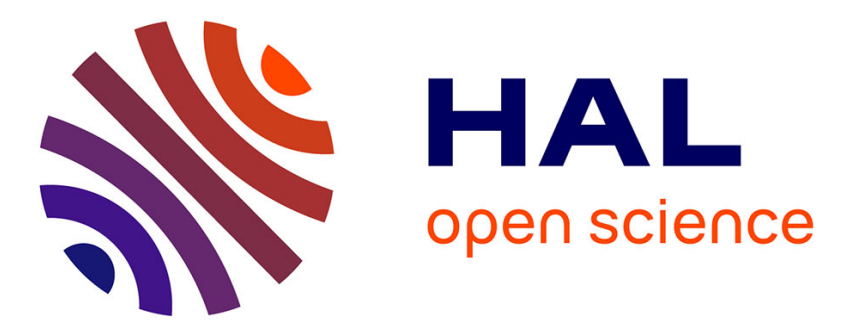

\title{
Quantifying the Eocene to Pleistocene topographic evolution of the soutwestern Alps, France and Italy
}

Séverine Fauquette, Matthias Bernet, Jean-Pierre Suc, Anne-Sabine Grosjean,

Stéphane Guillot, Peter van Der Beek, Sébastien Jourdan, Speranta-Maria

Popescu, Gonzalo Jiménez-Moreno, Adele Bertini, et al.

\section{To cite this version:}

Séverine Fauquette, Matthias Bernet, Jean-Pierre Suc, Anne-Sabine Grosjean, Stéphane Guillot, et al.. Quantifying the Eocene to Pleistocene topographic evolution of the soutwestern Alps, France and Italy. Earth and Planetary Science Letters, 2015, 412, pp.220-234. 10.1016/j.epsl.2014.12.036 . hal-01136399

\section{HAL Id: hal-01136399 \\ https://hal.science/hal-01136399}

Submitted on 27 Mar 2015

HAL is a multi-disciplinary open access archive for the deposit and dissemination of scientific research documents, whether they are published or not. The documents may come from teaching and research institutions in France or abroad, or from public or private research centers.
L'archive ouverte pluridisciplinaire HAL, est destinée au dépôt et à la diffusion de documents scientifiques de niveau recherche, publiés ou non, émanant des établissements d'enseignement et de recherche français ou étrangers, des laboratoires publics ou privés. 


\title{
Quantifying the Eocene to Pleistocene topographic evolution of the southwestern Alps, France and Italy
}

\author{
Séverine Fauquette $^{1 *}$, Matthias Bernet ${ }^{2}$, Jean-Pierre Suc ${ }^{3,4}$, Anne-Sabine Grosjean ${ }^{5,6}$, \\ Stéphane Guillot ${ }^{2}$, Peter van der Beek ${ }^{2}$, Sébastien Jourdan ${ }^{2}$, Speranta-Maria Popescu ${ }^{7}$, \\ Gonzalo Jiménez-Moreno ${ }^{8}$, Adele Bertini ${ }^{9}$, Bernard Pittet ${ }^{5}$, Pierre Tricart ${ }^{2}$, \\ Thierry Dumont ${ }^{2}$, Stéphane Schwartz ${ }^{2}$, Zhuo Zheng ${ }^{10}$, Emile Roche ${ }^{11}$, \\ Giulio Pavia $^{12}$, Véronique Gardien ${ }^{5}$
}

1, Institut des Sciences de l'Evolution, Université Montpellier 2, CNRS 5554, IRD, CC 061, Place Eugène Bataillon, 34095 Montpellier cedex 5, France (severine.fauquette@,univ-montp2.fr; phone number 33 467144179 )

2, ISTerre, Université Grenoble Alpes, CNRS, 1381 rue de la Piscine, 38041 Grenoble cedex, France (matthias.bernet@ujf-grenoble.fr, sebastien.p.jourdan@gmail.com, stephane.schwartz@ujf-grenoble.fr) s.guillot@ujf-grenoble.fr, tdumont@ujf-grenoble.fr, pvdbeek@ujf-grenoble.fr, Pierre.Tricart@ujf-grenoble.fr,

3, Sorbonne Universités, UPMC Univ. Paris 06, UMR 7193, Institut des Sciences de la Terre Paris (iSTeP), F-75005, Paris, France (jeanpierre.suc@gmail.com)

4, CNRS, UMR 7193, Institut des Sciences de la Terre Paris (iSTeP), F-75005, Paris, France

5, Laboratoire de Géologie de Lyon, Université Lyon 1/ENS Lyon, UMR 5276 CNRS, 2, rue Raphaël Dubois, 69622 Villeurbanne Cedex, France (annesabine.grosjean@gmail.com, Veronique.Gardien@univlyon1.fr, bernard.pittet@univ-lyon1.fr)

6, Laboratoire Magmas et Volcans, UMR CNRS 6524, Université Jean Monnet Saint-Etienne, 23 Rue Dr Paul Michelon, 42023 Saint-Etienne, France

7, GeoBioStratData.Consulting, 385 route du Mas Rillier, 69140 Rillieux la Pape, France (speranta.popescu@gmail.com)

8, Departamento de Estratigrafía y Paleontología, Universidad de Granada, Fuenta Nueva S/N, 18002 Granada, Spain (gonzaloj@ugr.es)

9, Dipartimento di Scienze della Terra, Università degli Studi di Firenze, Via G. La Pira, 450121 Firenze, Italy (adele.bertini@unifi.it)

10, Department of Earth Sciences, Sun Yat-sen University, Guangzhou 510275, China. (eeszzhuo@mail.sysu.edu.cn)

11, Université de Liège, Unité de Paléobotanique, de Paléopalynologie et de Micropaléontologie, Sart Tilman, Allée du 6 Août, B.18, 4000 Liège 1, Belgium (rocheemile@yahoo.fr)

12, Dipartimento di Scienze della Terra, Università di Torino, via Valperga 35, 10125 Torino, Italy (giulio.pavia@unito.it)

*Corresponding author, email: severine.fauquette@univ-montp2.fr 


\begin{abstract}
We evaluate the topographic evolution of the southwestern Alps using Eocene to Pleistocene pollen data combined with existing sedimentological, petrographic and detrital geo- and thermochronological data. We report 32 new pollen analyses from 10 sites completed by an existing dataset of 83 samples from 14 localities situated across the southwestern Alps, including both the pro- and the retro-foreland basins. The presence of microthermic tree pollen (mainly Abies, Picea) indicates that this part of the mountain belt attained elevations over $1900 \mathrm{~m}$ as early as the Oligocene. Inferred rapid surface uplift during the mid-Oligocene coincided with a previously documented brief phase of rapid erosional exhumation, when maximum erosion rates may have reached values of up to $1.5-2 \mathrm{~km} / \mathrm{Myr}$. Slower long-term average exhumation rates of $\sim 0.3 \mathrm{~km} / \mathrm{Myr}$ since the Late Oligocene helped maintaining the high Alpine topography of the southwestern Alps until today. The relative abundances of meso-microthermic tree pollen (Cathaya, Cedrus and Tsuga) and microthermic tree pollen (Abies, Picea) in the pro- and retro-foreland basin deposits, indicate that the present-day asymmetric topography, with a relatively gentle western flank and steeper eastern flank, was established early in the southwestern Alps, at least since the Early Miocene, and possibly since the Oligocene or Late Eocene. Therefore, the high topography and asymmetric morphology of this part of the Alps has been maintained throughout the past $230 \mathrm{Ma}$.
\end{abstract}

\title{
Keywords
}

Southwestern Alps, Topography, Pollen floras, Palaeo-elevation, Surface uplift, Late Paleogene-Neogene 


\section{Introduction}

The topography of mountain belts reflects the combined effects and feedback relationships of tectonic processes, which cause crustal thickening and surface uplift, and of climatically modulated surface processes, which create relief and tend to wear down mountainous topography (Willett, 1999; Whipple, 2009). Climate, in particular the amount, type and temporal distribution of precipitation, exerts a first-order control on weathering and erosion. The associated exhumation of rocks and mass redistribution at the surface influence the stress state and thermal structure of an orogen as part of the feedbacks within the system (Beaumont et al., 1992; Willett, 1999; Whipple and Meade, 2006). Different mechanisms have been proposed to explain the present-day topography and exhumation patterns of the European Alps, including crustal tectonics (Persaud and Pfiffner, 2004; Lardeaux et al., 2006), deepseated geodynamic processes (Lyon-Caen and Molnar, 1989; Sinclair, 1997a; Lippitsch et al., 2003; Kuhlemann, 2007; Baran et al., 2014) or climatically induced processes. In particular the spatial coincidence of the highest rock-uplift rates in areas of the largest relief and the most deeply incised glacial valleys suggest that a significant part of the currently observed surface uplift is driven by the isostatic response to Quaternary glacial erosion of the mountain belt (Schlunegger and Hinderer, 2001; Champagnac et al., 2007; Vernon et al., 2009).

The tectonic record within the interior of the belt suggests a complex evolution with an exhumation signal that varies strongly both spatially and temporally (Garzanti and Malusà, 2008; Morag et al., 2008; Glotzbach et al., 2009; Jourdan et al., 2013). In particular, the exhumation history of the internal zones of the Alps, characterized by an Alpine metamorphic overprint, contrasts strongly with that of the external massifs (Vernon et al., 2008; Beucher et al., 2012). This evolution, however, appears smoothed in the regional detrital record, leading to an apparent constancy of exhumation rates recorded by detrital thermochronology data (Bernet et al., 2001, 2009; Glotzbach et al., 2011; Bernet, 2013).

Initial subaerial exposure and erosional exhumation of the internal zones of the Western Alps may have occurred during the climax of collision and major backthrusting of the internal zones at $20 \mathrm{Ma}$ (Fügenshuh and Schmid, 2003; Tricart et al., 2006) as well as overfilling of the peripheral foreland basins (Sinclair, 1997b; Ford et al., 1999; Pfiffner et al., 2002; Ford and Lickorish, 2004; Jourdan et al., 2012; Schwartz et al., 2012). A second major event took place during Early Miocene times, when extensional reactivation of the Oligocene frontal thrust (Penninic thrust) led to a shift in the locus of maximum surface uplift from the internal to the external zones of the western Alps (Sue et al., 2007; Tricart et al., 2007). Surface uplift of the external crystalline massifs since this time (Leloup et al., 2005) led to drainage reorganisation from a radial to the present longitudinal pattern and thus influenced sediment routing systems (Schlunegger et al., 1998; Kühni and Pfiffner, 2001).

We address two key questions: (1) What have been the magnitude and tempo of the elevation changes in the past? (2) Since when has the Alpine topography been comparable to the present-day?

Our reconstruction of the topography of the southwestern Alps since the onset of collision in the Late Eocene is based on the record of synorogenic pro- and retro-foreland basin (sensu Naylor and Sinclair, 2008) deposits of the southwestern part of the belt. We use pollen analyses from Eocene and younger sediments coupled with previously published sedimentological, petrological, geochemical and geo-thermochronological sediment provenance and exhumation-rate data (Grosjean et al., 2012; Jourdan et al., 2012, 2013; Schwartz et al., 2012). We focus on two key phases, the Early Oligocene ( 34-28 Ma), when collisional tectonics affected the entire mountain belt, and the Miocene (23.5-5.3 Ma), when major decoupling occurred between the external and internal zones along the Penninic front. The depositional age of the studied units is based on published biostratigraphic data and on climatostratigraphic correlation with other well-dated pollen floras from the northwestern 
Mediterranean (Suc et al., 1995a, 1999; Fauquette et al., 2007; Jiménez-Moreno and Suc, 2007; Bertini and Martinetto, 2008). Latest Messinian to Pleistocene pollen floras (Fauquette et al., 2006) have also been considered to provide insights on the topographic evolution through time.

\section{Geological and morphological setting}

\subsection{Structure of the western Alps}

The European Alps result from closure of the Alpine Tethys Ocean followed by continental collision between the European and Adriatic plates since $\sim 35 \mathrm{Ma}$ (Schmid et al., 2004; Rosenbaum and Lister, 2005). The structure of the belt is characterized by a complex nappe stack, involving both basement and cover rocks of the European margin, the intervening ocean (Piedmont zone) and micro-continents, and the Adriatic margin. The Penninic front, a crustal-scale thrust fault, separates the western Alps into an internal and an external domain (Fig. 1). The internal western Alps consist, from east to west, of (1) highpressure/low-temperature metamorphic rocks of the internal crystalline massifs representing the most distal European margin (Dora-Maira, Gran Paradiso, Monte Rosa); (2) the Piedmont ("Schistes Lustrés") zone; (3) medium to low-grade metamorphic rocks of the Briançonnais zone (European margin); (4) the non-metamorphic Helminthoid flysch nappes and (5) the obducted Chenaillet ophiolite (Fig. 1). The external western Alps, to the west of the Penninic front, include the External Crystalline Massifs (Mont Blanc, Aiguilles Rouges, Belledonne, Pelvoux, Argentera-Mercantour), which consist of European basement rocks that were metamorphosed and intruded by granites during the Variscan orogeny, as well as PermoTriassic to Cretaceous sedimentary cover rocks of the former European passive margin (Fig. $1)$.

\subsection{Present-day topography}

The present-day mean elevation of the western Alps is $\sim 1500 \mathrm{~m}$, with about 60 mountain peaks over $4000 \mathrm{~m}$ in the Mont Blanc, Valais, Monte Rosa and Pelvoux massifs (Fig. 2A). Local relief reaches between $2000-3000 \mathrm{~m}$ in the northwestern and $1000-2000 \mathrm{~m}$ in the southwestern Alps (Vernon et al., 2009). Although the highest summits and relief are associated with the External Crystalline Massifs, the internal zones have the highest average topography. Topographic profiles across the north-, central- and south-western Alps (Fig. 2B) show a clear asymmetric topography, with a steep eastern flank and a somewhat gentler western flank.

\section{Data and methods}

\subsection{Modern pollen records}

Two transects were sampled across the southwestern Alps (Fig. 3 and Supplementary Table 1A) to obtain the pollen image of present-day vegetation. The pollen data (20 moss polsters and 2 recent lake sediments) are compared to the vegetation distribution along altitudinal and longitudinal gradients and are used as a reference to interpret Paleogene to Quaternary pollen records. The moss polsters have been processed using $\mathrm{KOH}(10 \%)$, whereas lake sediments were treated with $\mathrm{HCl}$ and $\mathrm{HF}$, both before sieving at $10 \mu \mathrm{m}$. Up to 150 pollen grains were counted, excluding Pinus generally over-represented in pollen data.

\subsection{Late Eocene to Mid-Pleistocene pollen records}

We searched for pollen grains in clayey sediments (see Tables 1 and 2 for information on their deposition environment) sampled close to coarser deposits in which mineralogical and thermochronological studies were performed previously. Most samples were collected from marine deposits of the foreland basins of the developing Alps, where abundant detrital 
sediments were supplied by the developing orogenic drainage system. In such sediments, pollen floras provide an unbiased record of the regional vegetation altitudinal belts, as established by studies on recent sediments (Heusser and Balsam, 1977; Heusser, 1988; Cambon et al., 1997; Beaudouin et al., 2005, 2007). A few samples have been collected in continental lacustrine, fluvial or lagoonal deposits.

Thirty-two new samples from 10 localities complete an existing dataset of 83 samples from 14 localities (Bessedik, 1985; Zheng and Cravatte, 1986; Zheng, 1990; Jiménez-Moreno, 2005; Suc et al., 1999; Hippolyte et al., 2011; Dubar, 1979). The total dataset thus contains data from 24 localities ranging from Late Eocene to Lower-Middle Pleistocene and distributed spatially on both flanks of the southwestern Alps (Fig. 1 and Supplementary Table 1B). Pollen identification following the botanical classification, based on high-level morphological examination, was accomplished at the finest possible taxonomic level by comparing the Paleogene and Neogene pollen grains with their present-day relatives using modern pollen collections. Percentages of taxa were calculated on the sum of the pollen grains and standard synthetic diagrams were drawn (Suc, 1984).

\subsection{Methods for estimating palaeo-elevations using pollen data}

The methods to quantify palaeo-elevations, developed by Fauquette et al. (1999) and Suc and Fauquette (2012) take into account pollen floras that provide a regional view of the vegetation from the lowermost up to the uppermost altitudinal belts within the drainage basin from which the sediments were sourced. The vertical shift of vegetation belts with latitude is obvious but difficult to quantify, as the altitudinal range of plant species is controlled by climatic parameters (decreasing temperature with altitude/latitude and concomitant increasing precipitation), but also by local conditions such as the nature of soils, slope orientation, etc. This organization of the vegetation was used by Ozenda $(1975,1989,2002)$ to establish a standard relationship in which modern vegetation belts shift $110 \mathrm{~m}$ in altitude per degree in latitude $\left(0.6^{\circ} \mathrm{C} /{ }^{\circ}\right.$ latitude vs $0.55^{\circ} \mathrm{C} / 100 \mathrm{~m}$ elevation). This relationship seems to be valid for all mountainous massifs of the northern hemisphere, between 70 and $30^{\circ} \mathrm{N}$ (Ozenda, 1989). The validity of the relationship is also demonstrated by detailed studies of the altitudinal limits of the vegetation in the Atlas Mountains of Morocco (Ozenda, 1975) and in the central Himalaya (Dobremez, 1972). The effect of the continentality may be important but our Neogene sites are situated in similar longitudinal position as the Alps today, so temporal variations in continentality will have been minimal. Therefore, using this altitude-latitude relationship together with the vegetation distribution and climatic estimates, palaeo-elevations may be assessed using fossil pollen records.

Microthermic trees inhabiting high elevation/ high latitude zones, such as Abies and Picea, represent the best indicators of elevated topography in the fossil pollen floras. Based on modern marine sediments close to the Alps (Suc et al., 1999), a threshold value of $\sim 3 \%$ for Abies and Picea has been used to infer the presence of forests of these taxa in the past (Fauquette et al., 1999). Nevertheless, pollen data do not allow estimating the altitudinal range of this vegetation belt, nor whether Alpine herbaceous and perpetual-snow belts existed above. This limitation is due to the difficulty of differentiating alpine herbaceous elements from those growing at lower elevations. As a consequence, these pollen-based palaeoelevations are minimum estimates corresponding to the lower limit of the highest forested belt.

Palaeo-elevation estimates are based on the mean annual temperature (MAT) estimated at low elevations by excluding microthermic taxa from the reconstruction process (Fauquette et al., 1998). This low-elevation temperature is subsequently used as the base to estimate minimum elevation in the source area of the sediments using the full pollen spectrum and the 
relation between altitudinal and latitudinal temperature gradients inferred by Ozenda (1975, $1989,2002)$. This procedure allows us to discriminate climatic variations from elevation changes.

Before the Tortonian, the latitudinal temperature gradient was weaker than the modern one in Europe; it was estimated by Fauquette et al. (2007) to be around $0.48{ }^{\circ} \mathrm{C} /{ }^{\circ}$ latitude during the Middle Miocene. We have similarly reconstructed the latitudinal temperature gradient for the Early Oligocene (Rupelian, 34-28 Ma) based on the MAT assessed from pollen records from significantly different palaeo-latitudes: Tongres, Belgium $\left(50^{\circ} 46^{\prime} \mathrm{N}\right.$, Roche and Schuler, 1976) where MAT $=17.5^{\circ} \mathrm{C}$ and Montauban, southern France $\left(44^{\circ} 01^{\prime} \mathrm{N}\right)$ where MAT $=19.6{ }^{\circ} \mathrm{C}$ (Fig. 4 and Supplementary Table 2). We find that the Rupelian latitudinal temperature gradient was also weaker than the modern; around $0.46{ }^{\circ} \mathrm{C} /{ }^{\circ}$ latitude. Hypothesizing that the ratio between altitudinal and latitudinal temperature gradients was similar to the present ratio during these times results in Rupelian and Middle-Miocene altitudinal temperature gradients of ca. $0.42{ }^{\circ} \mathrm{C}$ and $0.44{ }^{\circ} \mathrm{C} / 100 \mathrm{~m}$, respectively.

Prior to the Pliocene, Europe was situated at lower latitudes than today (Fig. 4; Meulenkamp and Sissingh, 2003). The palaeo-latitudes of the sites for which we have pollen data have therefore been estimated from palaeogeographic maps.

Our method for estimating palaeo-elevation from pollen data has previously been successfully applied to Early Pliocene (5.3 Ma) marine sediments from the foot of the Mercantour Massif, southeastern France, where it was validated by quantitative geomorphology (Fauquette et al., 1999). More recently, similar analyses have been applied to the Eastern Alps (Jiménez-Moreno et al., 2008), the Eastern Pyrenees (Suc and Fauquette, 2012) and the Apennines (Fauquette and Combourieu-Nebout, 2013; Fauquette et al., 2014).

\section{Results}

\subsection{Modern pollen flora transects}

Vegetation is similarly organized in altitudinal belts on both flanks of the mountain belt except for the occurrence of the Mediterranean evergreen belt at low elevations to the west (Fig. 5). Vegetation belts are organized altitudinally according to the concomitant decrease in temperature and increase in precipitation, and are defined by their dominant plant element(s) (Noirfalise et al., 1987; Ozenda, 2002).

Pollen grains have been grouped as much as possible to correspond to vegetation belts (Fig. 5). However, several complications could not be avoided and require some explanation. First, Pinus has been separated because its pollen grain is not identifiable at the species level. Therefore, this genus may represent several vegetation belts, although its abundance in samples from the 'Larix decidua' and 'Pinus cembro woods' belt or close to it (sites 4, 5, 6, 13, 15: Fig. 5) allows considering a probable origin from this belt in such cases. Second, pollen grains of Larix are scarcely recorded; samples containing this genus were collected almost exclusively within its forests (sites $4,5,13,15$ ) or from sites immediately below such forests (sites 7, 8, 10, 12, 14, 16, 18). Third, pollen grains of Cupressaceae (rare except in site 22) are grouped because they cannot be identified at the genus level, even though their species grow at different altitudes (Cupressus sempervirens and Juniperus oxycedrus in the two lowermost vegetation belts, $J$. communis in the subalpine belt, $J$. thurifera at higher elevations). Fourth, most of the herbaceous pollen grains cannot be distinguished at an infrafamily level, whereas such plants can inhabit different altitudes; their abundance may indicate open (site 1) and/or undergrowth (sites 2, 3, 5, 7, 9, 14, 15, 18, 19, 20, 21) vegetation. Finally, alpine tundra-like plants (Polygonum alpinum, Gentiana, Centaurea uniflora) have been identified in some sites $(4,6,13,15)$, sometimes in large quantities. There, some other plants have been ascribed to this group by deduction such as Alnus ascribed to A. viridis and Salix to a dwarf willow despite our inability to identify them at the species level. 
Wind transport may be important in mountainous regions and may lead to deposits recording pollen originating from other vegetation belts than that of the source area.

Despite these potential complications, the pollen data show a good correlation with the vegetation distribution along the slopes of the massifs and therefore faithfully record the different vegetation belts (Fig. 5). They also reflect the asymmetric elevation and therefore vegetation distribution along the two transects from west to east: the replacement of pollen groups as elevation increases appears progressive on the western flank but much more abrupt to the east (Fig. 5).

\subsection{Late Eocene to Mid-Pleistocene pollen floras}

Late Eocene to Pliocene pollen floras from both flanks of the southwestern Alps are characterized by prevalent mega-mesothermic plants (supporting subtropical conditions: MAT between 20 and $24^{\circ} \mathrm{C}$; Nix, 1982) and sometimes high frequencies of Cathaya (Fig. 6), a conifer living today in subtropical China at mid to high elevations, below the Abies and Picea belt (Wang, 1961). Megathermic plants (supporting tropical conditions: MAT $>24^{\circ} \mathrm{C}$; Nix, 1982) are present in all Eocene to Middle Miocene samples. The maximum frequency of such species was observed at Châteauredon the early Langhian age of which (Besson et al., 2005; Jiménez-Moreno and Suc, 2007) corresponds to the Mid-Miocene Climatic Optimum ( $\sim 15 \mathrm{Ma}$; Zachos et al., 2001, 2008). Mega-mesothermic pollen grains decrease from the early Zanclean ( $\sim 5 \mathrm{Ma})$ to the Piacenzian (3.6-2.6 Ma) (Fig. 6) and disappear from the pollen records at the earliest Pleistocene (2.6 Ma), probably due to the onset of Northern Hemisphere glaciations (Suc and Zagwijn, 1983; Suc, 1984; Bertini, 2010; Popescu et al., 2010).

On the whole, microthermic trees (supporting boreal conditions: MAT $<12^{\circ} \mathrm{C}$; $\mathrm{Nix}, 1982$ ) such as Abies and Picea occur in significantly higher frequencies on the eastern flank (Tetti Civera, Pavarolo, Borelli) than in the west, except at Vaugines (late Tortonian), located at the foot of the Luberon Massif, where high percentages of Abies and Cathaya are recorded. From the Early Miocene to the beginning of the Tortonian, samples from the eastern flank also show a significant abundance of the meso-microthermic (supporting cool-temperate conditions: MAT between 12 and $14^{\circ} \mathrm{C}$; Nix, 1982) tree Cedrus, whereas at the same time Cathaya is the most frequent high-elevation tree recorded on the western flank (Fig. 6).

\subsection{Palaeo-elevation estimates}

The minimum estimated palaeo-elevation (corresponding to the lower limit of the AbiesPicea belt) is relatively well constrained for periods prior to the Pliocene, when climate was tropical to subtropical in Europe, because the uppermost vegetation belt was most likely forested rather than herbaceous. For the Plio-Pleistocene, the presence of alpine tundra-like vegetation is expected above the fir-spruce-larch forest. However, pollen data do not allow establishing the presence of an alpine herbaceous belt above the highest forest belt due to the difficulty of unambiguously discriminating high-altitude herbs from other herbaceous pollen. Palaeo-elevation estimates are thus minimum values, restricted to the lower limit of the highest forest belt. The results presented in Table 1 correspond to the most probable palaeoelevations based on the Most Likely Values of MAT and, in brackets, to ranges of palaeoelevations based on the minimum and maximum MAT.

Most of the sites to the east of the range (Tetti Civera, Rio Civera, Pavarolo, Borelli, Torre Sterpi, Sioneri; Fig. 1) record pollen grains of Cathaya, Abies and Picea (Fig. 6) indicating high palaeo-elevations within the nearby massifs. In Gassino Torinese (Late Eocene; Fig. 6) Cathaya is the only meso-microthermic tree present (Table 1), indicating an altitude between 
950 and $1800 \mathrm{~m}$. However, this is also the only site in our dataset that predates the rapid Eocene-Oligocene cooling (Zachos et al., 2001; Hren et al., 2013). To the west of the southwestern Alps, the Oligocene Saint-Lions and Gambi sites (Figs. 1 and 6) indicate relatively high palaeo-elevations (1900 and $1740 \mathrm{~m}$, respectively; Table 1). However, the other pre-Zanclean sites do not show significant percentages of Abies and Picea. In some sites (Châteauredon, La Motte d'Aigues; Table 1; Fig. 6) Abies, Picea and Cathaya are completely absent. Considering the La Motte d'Aigues site, this absence may be due to the long distance from high-elevation pollen sources. Data from Châteauredon indicate the absence of high topography near this site. Early Zanclean to Early Piacenzian pollen data indicate high palaeoelevations in the source areas, except at Villeneuve for which high-elevation trees are represented mostly by Cathaya (Picea $<1 \%$; Table 1 ).

Table 2 displays the palaeo-elevation estimates for the continental sites. In this case, the estimated MLV of MAT from the pollen assemblage is compared to values inferred from a contemporaneous pollen flora representative of lowland vegetation. The estimates correspond in this case to the palaeo-elevations of the pollen localities themselves. The analysis shows that the Late Pliocene - Pleistocene sediments of Oraison-Flour, Les Mées-Périgoite, Le Rochassas sites were deposited at their modern elevations of 408, 522 and $820 \mathrm{~m}$ respectively (Table 2). In contrast, the pollen assemblage from Vaugines (Tortonian), at the foot of the Luberon Massif (1125 m), indicates a very low elevation during deposition (Table 2); this site has therefore been uplifted later to attain its modern elevation of $430 \mathrm{~m}$. However, the abundance of Abies and Cathaya in this pollen assemblage indicates nearby high elevations, estimated to be above $1670 \mathrm{~m}$ (Table 1).

\section{Discussion}

\subsection{Limitations of the method}

Numerous pollen studies (Roche and Schuler, 1976; Bessedik, 1985; Suc, 1989; Zheng, 1990; Suc et al., 1995a, b, 1999; Jiménez-Moreno, 2005; Bertini and Martinetto, 2011) have shown that the European vegetation of the Mid-Cenozoic follows a similar latitudinal and altitudinal belting to that observed in present-day southeastern China (Wang, 1961) where most of the taxa that disappeared from Europe by the Late Neogene still occur today. One of the plants indicating the existence of significant palaeo-elevations in our pollen data is Cathaya. However, the use of this genus in palaeoenvironmental reconstructions is not straightforward as it is currently considered as a relictual plant. Modern Cathaya is a monospecific genus (C. argyrophylla Chun and Kuang) restricted to southern China (Wang, 1961). Eight populations have been recorded in four provinces (Guangxi, Hunan, Sichuan, Guizhou; Mao, 1989). They are found between 950 and $1840 \mathrm{~m}$ elevation at latitudes between around $24^{\circ}$ and $29^{\circ} \mathrm{N}$. Thus, the modern habitat of Cathaya is located $\sim 10^{\circ}$ more to the south than the palaeo-latitudes of the Cenozoic western Alps sites (Fig. 4). However, present-day isotherms are also shifted $\sim 10^{\circ}$ in latitude to the south in eastern China in comparison to Europe. For our reconstructions, we thus consider minimum and maximum elevations of 950 $\mathrm{m}$ and $1800 \mathrm{~m}$, respectively, for Cathaya.

The altitude estimates of the sites were calculated using the Most Likely Values (MLV) of mean annual temperature (MAT) obtained from the pollen data. Although MLVs are less informative of climate than the entire reconstructed climatic amplitudes, as plants may sometimes support large climatic ranges, they provide a good estimation of the optimum conditions where the encountered plant assemblages best develop. Moreover, MLVs have been statistically tested on modern pollen data and are considered to provide reliable results (Fauquette et al., 1998). However, in order to provide an idea of the uncertainties, we also report the palaeo-elevation estimates based on the minimum and maximum MAT (in brackets in Table 1). 
We combine our pollen data with multiproxy provenance analyses from the same detrital sediments (Jourdan et al., 2012), together with reconstructions of the drainage network (Grosjean et al., 2012) in order to better constrain pollen sources. We can use this data because studies on recent marine coastal sediments have established that the contribution of airborne pollen to these sediments is negligible in comparison to fluvially transported pollen (Cambon et al., 1997; Beaudouin et al., 2007).

\subsection{Evolution of the western flank}

Rupelian sediments sampled in the Barrême Basin at Saint-Lions (Fig. 1) were sourced from the internal Alpine massifs (Piedmont zone close to the modern Monte Viso and Briançonnais zones), whereas Chattian sediments from the nearby Gambi site are dominated by local clastic input mixed with a low proportion of Alpine detritus (Evans and MangeRajetzky, 1991; Evans and Elliott, 1999; Morag et al., 2008; Jourdan et al., 2012; Schwartz et al., 2012). The pollen spectra from these sites include Cathaya, Cedrus, Tsuga, which indicate mid-elevations, as well as Picea and Abies indicating higher elevations, implying that as early as $\sim 30 \mathrm{Ma}$, a nearby massif attained elevations around $1900 \mathrm{~m}$ (1100 to $2900 \mathrm{~m}$ according to the minimum and maximum MAT) near Saint-Lions and $1740 \mathrm{~m}$ (1100 to $2900 \mathrm{~m})$ near Gambi. Given the configuration of the Oligocene drainage network (Fig. 7), in which both axial and transverse drainages were already established (Grosjean et al., 2012), the highelevation internal zone of the southwestern Alps, around the present-day Monte Viso, would be the most logical source for these high-altitude pollen.

The Early-Miocene (Aquitanian-Burdigalian) sites of Carros and Le Gourg close to Nice (Fig. 1), show the presence of Cathaya and Cedrus (Fig. 6) but insignificant percentages of Abies and Picea, implying the presence of an elevated massif in the source area during this time, the maximum elevation of which we estimate at $1800 \mathrm{~m}$ (Table 1). At present, the most proximal high-elevation massif for these sites is the External Crystalline ArgenteraMercantour Massif (Fig. 1). Using pollen data and quantitative geomorphological studies, Fauquette et al. (1999) showed that the Argentera-Mercantour Massif attained an elevation of $\sim 2000 \mathrm{~m}$ during the Pliocene. The exhumation of the Argentera-Mercantour Massif is supposed to start at 22 Ma (Corsini et al., 2004; Bigot-Cormier et al., 2006; Sanchez et al., 2011); it is therefore unlikely that the massif had already attained such high elevations in the late Early Miocene. An alternative source for pollen grains of microthermic and mesomicrothermic plants encountered in Carros and Le Gourg samples would have been northern Corsica and the conjugate Maures-Estérel Massif, as previously suggested by Suc et al. (1992). Apatite fission-track data from northwest Corsica indicate rapid exhumation around 15-25 Ma, attributed to rift-flank uplift in response to Ligurian rifting during the OligoceneEarly Miocene (Zarki-Jakni et al., 2004; Danišik et al., 2007).

Several Burdigalian to Serravallian ( 21-12 Ma) sites from the Durance Basin (La Rosée, Châteauredon, La Motte d'Aigues) do not record the presence of meso-microthermic and microthermic trees, except for Cathaya (Fig. 6). Although the ages of La Rosée and Châteauredon overlap the Miocene Climatic Optimum (Jiménez-Moreno, 2005), during which vegetation belts would have risen, our palaeo-elevation estimates correct for this effect and indicate low elevations in the source areas (Table 1). This suggests that, first, the Digne thrust sheet which today overthrusts the Miocene Châteauredon series and develops topography of up to $1000 \mathrm{~m}$ in its hanging-wall, had not yet been emplaced at $15 \mathrm{Ma}$. Second, rivers draining the mountainous hinterland would not yet have reached the marine palaeogulf of the Durance Basin in the Middle Miocene. While the topmost part of the Chateauredon section (Valensole Conglomerates) clearly evidences transport by the palaeo-Durance river, the Middle Miocene sediments do not record alpine clastic inputs. This suggests that the 
modern Durance drainage network was established in the Late Miocene (Aguilar and Clauzon, 1982).

The analysed sediments from La Motte d'Aigues post-date the Mid-Miocene cooling. However, the associated lowering of the vegetation belts is not recorded at this distal site. Only the pollen record from the Les Mées borehole encompasses the Mid-Miocene climatic extremes and shows a weak signal of the high-elevation conifers in its upper part (Fig. 6), probably recording their altitudinal descent due to global climatic cooling. Occurrence of high-elevation trees in these pollen records appears mainly controlled by the distance from the pollen source area and the organization of the drainage network.

The proximate early-Langhian Châteauredon and late-Piacenzian Le Rochassas sites bracket emplacement of the Digne thrust sheet and the modern drainage network to between $\sim 15$ and $\sim 3 \mathrm{Ma}$ (Hippolyte et al., 2011), as Le Rochassas samples indicate an elevation close to the modern elevation for this site (>800 m; Table 2) and provided a large amount of Picea pollen grains (Fig. 6), indicating the proximity of high topography. Likewise, pollen data from Villeneuve-Pigeonnier (Zanclean) show the presence of Cathaya among the mesomicrothermic trees. Picea is present in insignificant percentages and Abies is absent (Fig. 6; Table 1). This indicates, that, in contrast to the Burdigalian/Serravallian period ( 21-12 Ma), topography between 950 and $1800 \mathrm{~m}$ existed in the source area during the Early Pliocene. These results are also in agreement with inferred emplacement of the Digne thrust sheet during Miocene-Pliocene times (Jorda et al., 1988, 1992; Gidon, 1997; Fournier et al., 2008).

Finally, in the Serravallian ( $12-13 \mathrm{Ma})$ La Motte d'Aigues site, located $<15 \mathrm{~km}$ from the Luberon Massif, the absence of high-altitude tree pollen grains indicates that the Luberon Massif had not yet attained high elevations at that time. In contrast, high percentages of Abies pollen grains $(\sim 31 \%)$ in the middle Tortonian ( $\sim 9 \mathrm{Ma})$ Vaugines site, at the base of the Luberon Massif, show that high topography existed in the source area of this site, which is situated within a syncline filled by Miocene sediments derived from erosion of the Luberon anticline crest (Clauzon et al., 2011). Thus, our data is consistent with structural and topographic development of the Luberon Massif by south-directed thrusting during the time interval 10-6 Ma, as suggested by Clauzon et al. (2011).

The site of Vaugines is today at $430 \mathrm{~m}$ elevation, whereas during the middle Tortonian it was near sea level (Table 2). High temperatures during the Miocene (MAT between 10 and $23^{\circ} \mathrm{C}$, MLV around $17^{\circ} \mathrm{C}$ ) led to a positive shift of around $300 \mathrm{~m}$ of the vegetation belts (Table 1). In southern France, the lower altitudinal limit of the Abies belt is currently at 1400 m. Therefore, the occurrence of Abies in the Vaugines samples indicates source-area elevations above $\sim 1700 \mathrm{~m}$ in the Tortonian, while the maximum elevation of the modern Luberon Massif is $1125 \mathrm{~m}$ a.s.l. Our results therefore imply that $\sim 600 \mathrm{~m}$ surface lowering of the massif by erosion occurred since the Late Tortonian, whereas the foreland was uplifted by $\sim 400 \mathrm{~m}$.

Overall, sites from the western flank indicate the existence of high topography within the internal zone of the southwestern Alps since at least the Early Oligocene, together with outward propagation of deformation and structuring of the foreland during Late MiocenePliocene times (Fig.7). This finding is consistent with the westward migration of the main drainage divide between the Oligocene and Miocene inferred by Jourdan et al. (2012) from provenance data. All Late Oligocene to Miocene sites containing marine deposits are today several hundred meters above sea level, up to $855 \mathrm{~m}$ for Gambi. Thus, surface uplift of the western foreland must have taken place during the Neogene and Early Quaternary.

\subsection{Evolution of the eastern flank}

Late Eocene ( 37-34 Ma) clays sampled near Gassino Torinese belong to the Monte Piano Formation of the Torino Hills and are considered as distal Alpine deposits (Festa et al., 2011). 
The presence of Cathaya and the absence of Abies and Picea in these samples suggest palaeoelevations of 950 to $1800 \mathrm{~m}$. Jourdan et al. (2013) show that these early deposits in the Torino Hills were derived from the internal western Alps, suggesting the existence of proto-relief in this area already eroded by a palaeo-Dora Riparia drainage system (Fig. 7).

The sites in the Torino Hills that cover the Early to early Late Miocene (Tetti Civera, Rio Civera, Pavarolo, Borelli) indicate high palaeo-elevations of the nearby massifs, from $>1680$ $\mathrm{m}(1300-2250 \mathrm{~m})$ during the Aquitanian ( 23-20.5 Ma) up to $>1925 \mathrm{~m}(1465-2900 \mathrm{~m})$ during the mid-Tortonian ( $\sim 10 \mathrm{Ma})$. Pollen data from Torre Sterpi and Sioneri, covering the latest Messinian ( $\sim 6 \mathrm{Ma})$, indicate a minimum elevation around $1800 \mathrm{~m}(1400-2800 \mathrm{~m})$. However, we interpret this apparent lowering of the minimum elevation of the massif compared to previous periods as an artefact, due to the comparatively colder climate during Pliocene times and associated lowering of the Abies vegetation belt.

Thus, our pollen data from the eastern flank of the southwestern Alps suggest continuous high minimum elevations (of the order of $1800 \mathrm{~m}$ based on the MLV of MAT), since at least the Early Miocene and possibly since the Late Eocene.

\subsection{West-East dissymmetry in topography}

Late Paleogene and Early Neogene pollen spectra from the western flank of the southwestern Alps contain relatively high percentages of Cathaya, with respect to Abies and Picea. Likewise, Late Neogene samples contain relatively high percentages of Cedrus and Tsuga with respect to Abies and Picea. Conversely, the sites on the eastern flank show a relative balance between meso-microthermic (Cathaya, Cedrus and Tsuga) and microthermic (Abies and Picea) tree pollen.

This asymmetry between the two flanks of the mountain belt could be interpreted as a difference in temperature, the eastern flank being cooler than the western one. However, such an interpretation is contradicted by an equivalent abundance of megathermic and megamesothermic plants on both flanks (Fig. 6). The different proportions of meso-microthermic versus microthermic tree pollen are better explained by shorter pollen-transport routes from high elevations to the sedimentary sinks towards the east than towards the west, as also observed in the present-day pollen records (Fig. 5).

Pollen data from the western flank imply that the lowest conifer belt, constituted by Cathaya, Cedrus and Tsuga, was close to the sites of deposition and widely developed in space, and that a higher conifer belt constituted by Abies and Picea was far from these sites. This organization of the vegetation belts supports a relatively progressive increase in elevation on the western flank, as today (Fig. 2B). In contrast, pollen data from the eastern flank imply that both the lower and higher conifer belts were close to the Torino Hills sites, supporting an abrupt increase in elevation on the eastern flank of the southwestern Alps (Figs. 2B, 7). Therefore, the present-day topographic asymmetry of the southwestern Alps dates back to at least the Early Miocene, and possibly to the Oligocene or Late Eocene.

\subsection{Topography and exhumation}

In many orogenic belts, high topography is associated with high relief and erosion/exhumation rates (Montgomery and Brandon, 2002), as reflected by the present-day topography and exhumation patterns of the western Alps (Vernon et al., 2009). Unfortunately it is impossible to directly determine palaeo-relief from pollen or provenance data. Even though, in theory, detrital thermochronology data may allow information on palaeo-relief to be extracted (Stock and Montgomery, 1996), in practice the data are generally insufficiently resolved to permit this (Beucher et al., 2012; Olen et al., 2012). We know from previously published geo- and thermochronologic data (Bernet et al., 2009; Jourdan et al., 2013) as well as provenance studies (Evans and Mange-Rajetzky, 1991; Jourdan et al., 2012; Schwartz et 
al., 2012) that, during the Early Oligocene, local peak exhumation rates briefly increased to 1.5-2 km/Myr in the southwestern Alps (Morag et al., 2008; Jourdan et al., 2013), but average long-term exhumation rates remained much lower $(\sim 0.3 \mathrm{~km} / \mathrm{Myr})$ and fairly constant since $\sim 27 \mathrm{Ma}$ (Bernet et al., 2009). The timing of the peak exhumation rates during the Early Oligocene appears to coincide with the formation of high topography in the southwestern Alps. The slower long-term average exhumation rates would then reflect the persistence of this topography and its asymmetry until today. The westward shift of the southwestern Alps drainage divide during the Oligocene, as proposed by Jourdan et al. (2012) (Fig. 7), and the recent ( $<2 \mathrm{Ma}$ ) glacial modification of high topography in the western Alps (Glotzbach et al., 2013) are superimposed on this overall stable topographic setting.

\subsection{Geodynamic implications}

Von Blanckenburg and Davies (1995) proposed that in the northwestern and Central Alps slab break-off occurred between 35 and $30 \mathrm{Ma}$, driving the major and well-documented change from flysch to molasse deposition in the foreland basin at that time (Sinclair, 1997b). The seismic tomography data of Lippitsch et al. (2003) provide support for a slab break-off event, whereas Duretz et al. (2011) developed a theoretical framework for linking slab breakoff and the topographic evolution of the western Alps. These authors state that intermediate slab break-off at the oceanic-continental lithosphere transition causes surface uplift of the overriding plate at a rate of $0.5 \mathrm{~km} / \mathrm{Myr}$ after $c a$. $1 \mathrm{Ma}$, which is partly compatible with the inferences from detrital thermochronology data (Jourdan et al., 2013). Slab break-off followed by surface uplift is synchronous with anticlockwise rotation of the Apulian plate, a change in the convergence direction from south-north to east-west between the Apulian and Eurasian plates, and crustal thickening during continent-continent collision, which all started at about 35-30 Ma (Handy et al., 2010; Malusà et al., 2011; Dumont et al., 2012). This generalized and sharp kinematic change is linked to slab retreat in the nascent Mediterranean realm, inducing strong westward mantle flow beneath the southwestern Alps (Jolivet et al., 2009). However, while slab break-off can account for a general uplift of the Alps during the Early Oligocene, it cannot explain the localized uplift and the dissymmetry recorded at that time in the western Alps.

Theoretical models of doubly-vergent critical wedges (Willett et al., 1993; Whipple and Meade, 2006) predict that the retro-wedge should be steeper than the pro-wedge, consistent with the palaeo-elevation and exhumation record of the southwestern Alps (Carrapa, 2009; this study). Moreover, geophysical analyses of the deep structure of the Western Alps show the presence of the high-velocity, high-density Ivrea body in the core of the orogenic arc, at less than $10 \mathrm{~km}$ depth (Schmid and Kissling, 2000; Paul et al., 2001; Lardeaux et al., 2006). The Ivrea body, which is interpreted as a sliver of Apulian mantle, acts as a vertical indenter against the European plate during east-west convergence (Lardeaux et al., 2006). This indenter may have supported localized surface uplift in the internal western Alps and further explain the topographic dissymmetry recorded by sediment provenance (Schwartz et al., 2012; Jourdan et al., 2012, 2013; Fig. 7).

Sites from the western foreland show significant (up to $800 \mathrm{~m}$ ) surface uplift since the Late Miocene (Section 5.2). Up to $500 \mathrm{~m}$ of foreland uplift can be attributed to the flexural isostatic response to increased Quaternary erosional unloading of the western Alps (Champagnac et al., 2008), which would lead to net surface lowering of the mountain range. The remainder could possibly be attributed to deep-seated geodynamic processes, such as renewed slab break-off (Kuhlemann, 2007; Baran et al., 2014), for which geophysical evidence remains scarce, however (Lippitsch et al., 2003). 


\section{Conclusions}

We show that the topography of the internal zone of the southwestern Alps could have reached elevations around $1800 \mathrm{~m}$ as early as the Oligocene $(\sim 30 \mathrm{Ma})$. In contrast, the external massifs, including the Mercantour Massif in the southwestern Alps, were uplifted later, during the Late Neogene, while emplacement of the external Digne thrust nappe occurred after the Serravallian ( $\sim 12-13 \mathrm{Ma})$. Pollen data show that the present-day topographic asymmetry of the southwestern Alps, with a relatively gentle western flank and much steeper eastern flank, dates back to at least the Early Miocene, and possibly to the Oligocene or Late Eocene.

This topographic evolution is coherent with provenance data and estimates of exhumation rate from detrital thermochronology from the same sedimentary units in the pro- and retroforeland basins. Rapid surface uplift during the Early Oligocene coincided with a brief episode of rapid exhumation; the high topography of the internal zones of the southwestern Alps has been maintained with moderate long-term average rates of exhumation since that time. Westward propagation of deformation in the Miocene-Pliocene and Quaternary glacial erosion has not severely perturbed this overall stable system.

\section{Acknowledgements}

This is a contribution to the project "Erosion and Relief Development in the Western Alps" funded by the Agence Nationale de la Recherche (ANR-08-BLAN-0303-01). Information on Cathaya has been collected during the Project T00-04 of the Association Franco-Chinoise pour la Recherche Scientifique et Technique. J.-L. de Beaulieu is acknowledged for providing some modern pollen analyses and S. Ferry for sampling some mosses. Two anonymous reviewers helped us to improve the manuscript. This is ISEM contribution $\mathrm{n}^{\circ * * * * * * *}$. 


\section{References}

Aguilar, J.-P., Clauzon, G., 1982. Evolution géodynamique de la Provence septentrionale au cours du Miocène supérieur et terminal d'après les faunes de Rongeurs. Comptes Rendus de l'Académie des Sciences de Paris série 2 294, 915-920.

Aguilar, J.-P., Dubar, M., Michaux, J., 1982. Nouveaux gisements à rongeurs dans la formation de Valensole : La Tour près de brunet, d'âge Miocène supérieur (Messinien) et le Pigeonnier de l'Ange près de Villeneuve, d'âge Pliocène moyen. Implications stratigraphiques. Comptes Rendus de l'Académie des Sciences de Paris série 2 295, 745 750.

Baran, R., Friedrich, A.M., Schlunegger, F., 2014. The late Miocene to Holocene erosion pattern of the Alpine foreland basin reflects Eurasian slab unloading beneath the western Alps rather than global climate change. Lithosphere 6, 124-131.

Beaudouin, C., Suc, J.-P., Cambon, G., Touzani, A., Giresse, P., Pont, D., Aloïsi, J.-C., Marsset, T., Cochonat, P., Duzer, D., Ferrier, J., 2005. Present-day rhythmic deposition in the Grand Rhone Prodelta (NW Mediterranean) according to high-resolution pollen analyses. Journal of Coastal Research 21, 292-306.

Beaudouin, C., Suc, J.-P., Escarguel, G., Arnaud, M., Charmasson, S., 2007. The significance of pollen signal in present-day marine terrigenous sediments: The example of the Gulf of Lions (western Mediterranean Sea). Geobios 40, 159-172.

Beaumont, C., Fullsack, P., Hamilton, J., 1992. Erosional control of active compressional orogens, in: McClay, K.R. (Ed.), Thrust Tectonics. Chapman \& Hall, London, pp. 1-18.

Bernet, M., 2013. Detrital zircon fission-track thermochronology of the present-day Isère River drainage system in the Western Alps: no evidence for increasing erosion rates at 5 Ma. Geosciences 3, 528-542.

Bernet, M., Brandon, M.T., Garver, J.I., Balestrieri, M.L., Ventura, B., Zattin, M., 2009. Exhuming the Alps through time: Clues from detrital zircon fission-track ages. Basin Research 21, 781-798.

Bernet, M., Zattin, M., Garver, J.I., Brandon, M.T., Vance, J.A., 2001. Steady-state exhumation of the European Alps. Geology 29, 35-38.

Bertini, A., 2010. Pliocene to Pleistocene palynoflora and vegetation in Italy: state of the art. Quaternary International 225, 5-24.

Bertini, A., Martinetto, E., 2008. Messinian to Zanclean vegetation and climate of Northern and Central Italy. Bolletino della Società Paleontologica Italiana 47, 2, 105-121.

Bertini, A., Martinetto, E., 2011. Reconstruction of vegetation transects for the MessinianPiacenzian of Italy by means of comparative analysis of pollen, leaf and carpological records. Palaeogeography, Palaeoclimatology, Palaeoecology 304, 230-246.

Bessedik, M., 1985. Reconstitution des environnements Miocènes des régions nord-ouest Méditerranéennes à partir de la palynologie. Ph.D. Thesis, University Montpellier 2, France, $162 \mathrm{pp}$.

Besson, D., Parize, O., Rubino, J.-L., Aguilar, J.-P., Aubry, M.-P., Beaudoin, B., Berggren, W.A., Clauzon, G., Crumeyrolle, P., Dexcoté, Y., Fiet, N., Iacarino, S., Jiménez-Moreno, G., Laporte-Galaa, C., Michaux, J., von Salis, K., Suc, J.-P., Reynaud, J.-Y., Wernli, R., 2005. Un réseau fluviatile d'âge burdigalien terminal dans le sud-est de la France: remplissage, extension, âge, implications. Comptes Rendus Geosciences, Stratigraphie, Géomorphologie 337, 1045-1054.

Beucher, R., van der Beek, P., Braun, J., Batt, G.E., 2012. Exhumation and relief development in the Pelvoux and Dora-Maira massifs (western Alps) assessed by spectral analysis and inversion of thermochronological age transects. Journal of Geophysical Research 117, F03030, doi: 10.1029/2011jf002240. 
Bigot-Cormier, F., Sosson, M., Poupeau, G., Stéphan, J.-F., Labrin, E., 2006. The denudation history of the Argentera Alpine External Crystalline Massif (Western Alps, France-Italy): an overview from the analysis of fission tracks in apatites and zircons. Geodinamica Acta $19,455-473$.

Calais, E., Nocquet, J.-M., Jouanne, F., Tardy, M., 2002. Current strain regime in the Western Alps from continuous Global Positioning System measurements, 1996-2001. Geology 30, 651-654.

Cambon, G., Suc, J.-P., Aloisi, J.-C., Giresse, P., Monaco, A., Touzani, A., Duzer, D., Ferrier, J., 1997. Modern pollen deposition in the Rhône delta area (lagoonal and marine sediments), France. Grana 36, 105-113.

Carrapa, B., 2009. Tracing exhumation and orogenic wedge dynamics in the European Alps with detrital thermochronology. Geology 37, 1127-1130.

Champagnac, J.D., Molnar, P., Anderson, R.S., Sue, C., Delacou, B., 2007. Quaternary erosion-induced isostatic rebound in the western Alps. Geology 35, 195-198.

Champagnac, J.-D., van der Beek, P., Diraison, G., Dauphin, S., 2008. Flexural isostatic response of the Alps to increased Quaternary erosion recorded by foreland basin remnants, SE France. Terra Nova 20, 213-220.

Clauzon, G., Fleury, T.-J., Bellier, O., Molliex, S., Mocochain, L., Aguilar, J.-P., 2011. Morphostructural evolution of the Luberon since the Miocene (SE France). Bulletin de la Société géologique de France 182, 2, 95-110.

Corselli, C., Grecchi, G., 1984. The passage from hypersaline to hyposaline conditions in the Mediterranean Messinian: discussion of the possible mechanisms triggering the «lagomare» facies. Paléobiologie Continentale 14, 2, 225-239.

Corsini, M., Ruffet, G., Caby, R., 2004. Alpine and late-hercynian geochronological constraints in the Argentera Massif (Western Alps). Eclogae geologicae Helvetiae 97, 315.

Couëffé, R., Tessier, B., Gigot, P., Beaudoin, B., 2004. Tidal rhythmites as possible indicators of very rapid subsidence in a foreland basin: an example from the Miocene marine Molasse Formation of the Digne foreland basin, SE France. Journal of Sedimentary Research 74, 6, 746-759.

Danišík, M., Kuhlemann, J., Dunkl, I., Székely, B., Frisch, W., 2007. Burial and exhumation of Corsica (France) in the light of fission track data. Tectonics 26, TC1001, doi: 10.1029/2005TC001938.

Dobremez, J.F., 1972. Le Népal, phytogéographie et écologie. CNRS ed., Paris.

Dubar, M., 1979. Les gisements de Flour et de Périgoite 522 sur la haute terrasse inférieure de la rive gauche de la moyenne Durance. Bulletin de l'Association française pour l'Etude du Quaternaire 3, 139-146.

Dubois, P., Curnelle, R., 1978. Résultats apportés par le forage Les Mées 1 sur le plateau de Valensole (Alpes-de-Haute-Provence). Comptes Rendus sommaires de la Société Géologique de France 4, 181-184.

Dumont, T., Schwartz, S., Guillot, S., Simon-Labric, T., Tricart, P., Jourdan, S., 2012. Structural and sedimentary records of the Oligocene revolution in the Western Alpine arc. Journal of Geodynamics 56-57, 18-38.

Duretz, T., Gerya, T.V., May, D.A., 2011. Numerical modelling of spontaneous slab breakoff and subsequent topographic response. Tectonophysics 502, 244-256.

Evans, M.J., Elliott, T., 1999. Evolution of a thrust-sheet-top basin: the Tertiary Barrême basin, Alpes-de-Haute-Provence, France. Geological Society of America Bulletin 111, 1617-1643. 
Evans, M.J., Mange-Rajetzky, M.A., 1991. The provenance of sediments in the Barrême thrust-top basin, Hate-Provence, France, in: Morton, A.C., Todd, S.P., Haughton, P.D.W. (Eds), Development in Sedimentary Provenance Studies. Geological Society of London, Special Publications 57, 323-342.

Fauquette, S., Bertini, A., Manzi, V., Roveri, M., Argnani, A., Menichetti, E., 2014. Reconstruction of the Northern and Central Apennines (Italy) palaeoaltitude during the late Neogene from pollen data. Review of Palaeobotany and Palynology, in press.

Fauquette, S., Clauzon, G., Suc, J.-P., Zheng, Z., 1999. A new approach for palaeoaltitude estimates based on pollen records: example of the Mercantour Massif (Southeastern France) at the Earliest Pliocene. Earth and Planetary Science Letters 170, 35-47.

Fauquette, S., Combourieu-Nebout, N., 2013. Palaeoaltitude of the Sila Massif (Southern Apennines, Italy) and distribution of the vegetation belts at $c a$. 2.4 Ma (Early Pleistocene). Review of Palaeobotany and Palynology 189, 1-7.

Fauquette, S., Guiot, J., Suc, J.-P., 1998. A method for climatic reconstruction of the Mediterranean Pliocene using pollen data. Palaeogeography, Palaeoclimatology, Palaeoecology 144, 183-201.

Fauquette, S., Suc, J.-P., Bertini, A., Popescu, S.-M., Warny, S., Bachiri Taoufiq, N., Perez Villa, M. J., Chikhi, H., Feddi, N., Subally, D., Clauzon, G., Ferrier J., 2006. How much did the climate force the Messinian salinity crisis? Quantified climatic conditions from pollen records in the Mediterranean region. Palaeogeography, Palaeoclimatology, Palaeoecology 238, 281-301.

Fauquette, S., Suc, J.-P., Jiménez-Moreno, G., Micheels, A., Jost, A., Favre, E., BachiriTaoufiq, N., Bertini, A., Clet-Pellerin, M., Diniz, F., Farjanel, G., Feddi, N., Zheng, Z., 2007. Latitudinal climatic gradients in western European and Mediterranean regions from the Mid-Miocene ( $\sim 15 \mathrm{Ma})$ to the Mid-Pliocene ( $\sim 3.5 \mathrm{Ma})$ as quantified from pollen data, in: Williams, M., Haywood, A., Gregory, J., Schmidt, D. (Eds.), Deep time perspectives on climate change: marrying the signal from computer models and biological proxies. The Micropalaeontological Society, Special Publications. The Geological Society, London, 481-502.

Festa, A., Dela Pierre, F., Irace, A., Piana, F., Fioraso, G., Lucchesi, S., Boano, P., Forno, M.G., 2011. Carta geologica d'Italia 156, Torino Est, scale 1:50,000.

Ford, M., Lickorish, W.H., 2004. Foreland basin evolution around the Western Alpine arc, in: Joseph, P., Lomas, S.A. (Eds), Deep-Water Sedimentation in the Alpine Basin of SE France: New perspectives on the Grès d'Annot and related systems. Geological Society, London, Special Publications 221, 39-63.

Ford, M., Lickorish, W.H., Kusznir, N.J., 1999. Tertiary foreland sedimentation in the southern subalpine chains, SE France: a geodynamical appraisal. Basin Research 11, 315336.

Fournier, M., Agard, P., Petit, C., 2008. Micro-tectonic constraints on the evolution of the Barles half-window (Digne nappe, Southern Alps). Implications for the timing of folding in the Valensole foreland basin. Bulletin de la Société géologique de France 179, 551-568.

Fügenschuh, B., Schmid, S.M., 2003. Late stages of deformation and exhumation of an orogen constrained by fission-track data: A case study from the Western Alps. Geological Society of America Bulletin 115, 1425-1440.

Garzanti, E., Malusà, M.G., 2008. The Oligocene Alps: Domal unroofing and drainage development during early orogenic growth. Earth and Planetary Science Letters 268, 487 500 .

Gidon, M., 1997. Les chaînons subalpins au nord-est de Sisteron et l'histoire tectonique de la nappe de Digne. Géologie Alpine 73, 23-57. 
Glotzbach, C., Spiegel, C., Reinecker, J., Rahn, M., Frisch, W., 2009. What perturbs isotherms? An assessment using fission track thermochronology and thermal modelling along the Gotthard transect, Central Alps, in: Lisker F., Ventura B., Glasmacher U. (Eds.), Thermochronological methods: from paleotemperature constraints to landscape evolution models. Geological Society of London, Special Publication 324, 111-124.

Glotzbach, C., Bernet, M., van der Beek, P., 2011. Detrital thermochronology records changing source areas and steady exhumation in the Western and Central European Alps. Geology 39, 239-242.

Glotzbach, C., van der Beek, P., Carcaillet, J., Delunel, R., 2013. Deciphering the driving forces of erosion rates on millennial to million-year timescales in glacially impacted landscapes: An example from the Western Alps. Journal of Geophysical Research: Earth Surface 118, 1491-1515.

Grosjean, A.-S., Pittet, B., Ferry, S., Mahéo, G., Gardien, V., 2012. Reconstruction of Tertiary palaeovalleys in the South Alpine Foreland basin of France (Eocene-Oligocene of the Castellane arc). Sedimentary Geology 275-276, 1-21.

Handy, M.R., Schmid, S.M., Bousquet, R., Kissling, E., Bernoulli, D., 2010. Reconciling plate-tectonic reconstructions of Alpine Tethys with the geological-geophysical record of spreading and subduction in the Alps. Earth-Science Reviews 102, 121-158.

Heusser, L.E., 1988. Pollen distribution in marine sediments on the continental margin off northern California. Marine Geology 80, 131-147.

Heusser, L.E., Balsam, W.L., 1977. Pollen distribution in the Northeast Pacific Ocean. Quaternary Research 7, 45-62.

Hippolyte, J.-C., Clauzon, G., Suc, J.-P., 2011. Messinian-Zanclean canyons in the Digne nappe (Southern Alps): tectonic implications. Bulletin de la Société géologique de France $182,2,111-132$.

Hren, M.T., Sheldon, N.D., Grimes, S.T., Collinson, M.E., Hooker, J.J., Bugler, M., Lohmann, K.C., 2013. Terrestrial cooling in Northern Europe during the EoceneOligocene transition. Proceedings National Academy of Sciences 110, 7562-7567.

Jiménez-Moreno, G., 2005. Utilización del análisis polínico para la reconstrucción de la vegetación, clima y paleoaltitudes a lo largo del arco alpino europeo durante el Mioceno (21-8 Ma). Ph.D. Thesis, University of Granada, Spain.

Jiménez-Moreno, G., Fauquette, S., Suc, J.-P., 2008. Vegetation, climate and palaeoaltitude reconstructions of the Eastern Alps during the Miocene based on pollen records from Austria, Central Europe. Journal of Biogeography 35, 1638-1649.

Jiménez-Moreno, G., Suc, J.-P., 2007. Middle Miocene latitudinal climatic gradient in western Europe: evidence from pollen records. Palaeogeography, Palaeoclimatology, Palaeoecology 253, 224-241.

Jolivet, L., Faccenna, C., Piromallo, C., 2009. From Mantle to crust: stretching the Mediterranean. Earth and Planetary Science Letters 285, 198-209.

Jorda, M., Combes, P., Philip, H., 1992. Tectogenèse et morphogenèse quaternaires des chaînes subalpines méridionales (région de Digne et vallée de la Bléone). Quaternaire 3, 129-135.

Jorda, M., Roiron, P., Vernet, J.-L., 1988. La formation alluviale à flore fossile des fontaines (Digne - Alpes de Haute-Provence): un jalon important dans l'évolution tectorogénique tardive de 1'arc subalpin de Digne. Géologie Alpine 64, 49-60.

Jourdan, S., Bernet, M., Schwartz, S., Guillot, S., Tricart, P., Chauvel, C., Dumont, T., Montagnac, G., Bureau, S., 2012. Tracing the Oligocene-Miocene evolution of the Western Alps drainage divide with pebble petrology, geochemistry and Raman spectroscopy of foreland basin deposits. Journal of Geology 120, 603-624. 
Jourdan, S., Bernet, M., Tricart, P., Hardwick, E., Paquette, J.L., Guillot, S., Dumont, T., Schwartz, S., 2013. Short-lived fast erosional exhumation of the internal Western Alps during the late Early Oligocene: constraints from geo-thermochronology of pro- and retroside foreland basin sediments. Lithosphere 5, 211-225.

Kuhlemann, J., 2007. Paleogeographic and paleotopographic evolution of the Swiss and Eastern Alps since the Oligocene. Global and Planetary Change 58, 224-236.

Kühni, A., Pfiffner, O.A., 2001. Drainage patterns and tectonic forcing: a model study for the Swiss Alps. Basin Research 13, 169-197.

Lardeaux, J.M., Schwartz, S., Tricart, P., Paul, A., Guillot, S., Bethoux, N., Masson, F., 2006. A crustal-scale cross-section of the south-western Alps combining geophysical and geological imagery. Terra Nova 18, 412-422.

Leloup, P.H., Arnaud, N., Sobel, E.R., Lacassin, R., 2005. Alpine thermal and structural evolution of the highest external crystalline massif: the Mont Blanc. Tectonics 24, TC4002, doi:10.1029/2004TC001676.

Lippitsch, R., Kissling, E., Ansorge, J., 2003. Upper mantle structures beneath the Alpine orogen from high-resolution teleseismic tomography. Journal of Geophysical Research 108, 1-15.

Lyon-Caen, H., Molnar, P., 1989. Constraints on the deep structure and dynamic processes beneath the Alps and adjacent regions from an analysis of gravity anomalies. Geophysical Journal International 99, 19-32.

Malusà, M.G., Faccenna, C. Garzanti, E., Polino, R. 2011. Divergence in subduction zones and exhumation of high pressure rocks (Eocene Western Alps). Earth and Planetary Science Letters 310, 21-32.

Mao, Z.Z., 1989. Cathaya argyrophylla, an endemic tree of China, its resources, distribution and environment. Guihaia 9, 1-11.

Meulenkamp, J.E., Sissingh, W., 2003. Tertiary palaeogeography and tectonostratigraphic evolution of the Northern and Southern Peri-Tethys platforms and the intermediate domains of the African-Eurasian convergent plate boundary zone. Palaeogeography, Palaeoclimatology, Palaeoecology 196, 209-228.

Montgomery, D.R., Brandon, M.T., 2002. Topographic controls on erosion rates in tectonically active mountain ranges. Earth and Planetary Science Letters 201, 481-489.

Morag, N., Avigad, D., Harlavan, Y., McWilliams, M.O., Michard, A., 2008. Rapid exhumation and mountain building in the Western Alps: Petrology and 40Ar/39Ar geochronology of detritus from Tertiary basins of southeastern France. Tectonics 27, TC2004, doi:10.1029/2007TC002142.

Naud, G., Suc, J.-P., 1975. Contribution à l'étude paléofloristique des Coirons (Ardèche): premières analyses polliniques dans les alluvions sous-basaltiques et interbasaltiques de Mirabel (Miocène supérieur). Bulletin de la Société Géologique de France série 7, XVII, 820-829.

Naylor, M., Sinclair, H.D., 2008. Pro- vs. retro-foreland basins. Basin Research 20, 285-303.

Nix, H., 1982. Environmental determinants of biogeography and evolution in Terra Australis, in: Barker, W.R., Greenslade, P.J.M. (Eds.), Evolution of the Flora and fauna of Arid Australia. Peacock Publishing, Frewville, pp. 47-66.

Noirfalise, A., Dahl, E., Ozenda, P., Quézel, P., 1987. Carte de la végétation naturelle des états membres des communautés européennes et du conseil de l'Europe. Office des publications officielles des Communautés européennes, Luxembourg, 78 pp.

Olen, S.M., Ehlers, T.A., Densmore, M.S., 2012. Limits to reconstructing paleotopography from thermochronometer data. Journal of Geophysical Research 117, F01024.

Ozenda, P., 1975. Sur les étages de végétation dans les montagnes du bassin méditerranéen. Documents de Cartographie Ecologique, Grenoble 16, 1-32. 
Ozenda, P., 1989. Le déplacement vertical des étages de végétation en fonction de la latitude: un modèle simple et ses limites. Bulletin de la Société Géologique de France 8, 535-540.

Ozenda, P., 2002. Perspectives pour une géobiologie des montagnes. Presses polytechniques et universitaires romandes, Lausanne, Switzerland, $195 \mathrm{p}$.

Paul, A., Cattaneo, M., Thouvenot, F., Spallarossa, D., Béthoux, N., Fréchet, J., 2001. A three-dimensional crustal velocity model of the southwestern Alps from local earthquake tomography. Journal of Geophysical Research 106, 19367-19389.

Persaud, M., Pfiffner, O.A., 2004. Active tectonics in the eastern Swiss Alps: post-glacial faults, seismicity and surface uplift. Tectonophysics 385, 59-84.

Pfiffner, O.A., Schlunegger, F., Buiter, S., 2002. The Swiss Alps and their peripheral foreland basin: stratigraphic response to deep crustal processes. Tectonics 21, 1009, 10.1029/2000TC900039.

Popescu, S.-M., Biltekin, D., Winter, H., Suc, J.-P., Melinte-Dobrinescu, M.C., Klotz, S., Combourieu-Nebout, N., Rabineau, M., Clauzon, G., Deaconu, F., 2010. Pliocene and Lower Pleistocene vegetation and climate changes at the European scale: Long pollen records and climatostratigraphy. Quaternary International 219, 152-167.

Roche, E., Schuler, M., 1976. Analyse palynologique (pollen et spores) de divers gisements du Tongrien de Belgique. Interprétation paléoécologique et stratigraphique. Service Géologique de Belgique, Professional Paper $n^{\circ} 11,1-57$.

Rosenbaum, G., Lister, G.S., 2005. The Western Alps from the Jurassic to Oligocene: Spatiotemporal constraints and evolutionary reconstructions. Earth-Science Reviews 69, 281306.

Ryan, W.B.F., Carbotte, S.M., Coplan, J.O., O’Hare, S., Melkonian, A., Arko, R., Weissel, R.A., Ferrini, V., Goodwillie, A., Nitsche, F., Bonczkowski, J., Zemsky, R., 2009. Global Multi-Resolution Topography synthesis. Geochemistry, Geophysics, Geosystems 10, Q03014, doi:10.1029/2008GC002332.

Sanchez, G., Rolland, Y., Jolivet, M., Brichau, S., Corsini, M., Carter, A., 2011. Exhumation controlled by transcurrent tectonics: the Argentera-Mercantour massif (SW Alps). Terra Nova 23, 116-121.

Schlunegger, F., Hinderer, M., 2001. Crustal uplift in the Alps: why the drainage pattern matters. Terra Nova 13, 425-432.

Schlunegger, F., Slingerland, R., Matter, A., 1998. Crustal thickening and crustal extension as controls on the evolution of the drainage network of the central Swiss Alps between $30 \mathrm{Ma}$ and the present; constraints from the stratigraphy of the North Alpine Foreland basin and the structural evolution of the Alps. Basin Research 10, 197-212.

Schmid, S.M., Fügenschuh, B., Kissling, E., Schuster, R., 2004. Tectonic map and overall architecture of the Alpine orogen. Eclogae geologicae Helveticae 97, 93-117.

Schmid, S.M., Kissling, E., 2000. The arc of the western Alps in the light of geophysical data on deep crustal structure. Tectonics 19, 62-85.

Schwartz, S., Guillot, S., Tricart, P., Bernet, M., Jourdan, S., Dumont, T., Montagnac, C., 2012. Source tracing of detrital serpentinite in the Oligocene molasse deposits from the western Alps (Barrême basin): implications for relief formation in the internal zone. Geological Magazine 149, 841-856.

Serpelloni, E., Anzidei, M., Baldi, P., Casula, G., Galvani, A., 2005. Crustal velocity and strain-rate fields in Italy and surrounding regions: new results from the analysis of permanent and non-permanent GPS networks. Geophysical Journal International 161, 861880.

Sinclair, H.D., 1997a. Tectonostratigraphic model for underfilled peripheral foreland basins: An Alpine perspective. Geological Society of America Bulletin 109, 324-346. 
Sinclair, H.D., 1997b. Flysch to molasse transition in peripheral foreland basins: The role of the passive margin versus slab breakoff. Geology 25, 1123-1126.

Stock, J.D., Montgomery, D.R., 1996. Estimating paleorelief from detrital mineral ages. Basin Research 8, 317-327.

Suc, J.-P., 1984. Origin and evolution of the Mediterranean vegetation and climate in Europe. Nature 307, 429-432.

Suc, J.-P., 1989. Distribution latitudinale et étagement des associations végétales au Cénozoïque supérieur dans l'aire ouest-méditerranéenne. Bulletin de la Société géologique de France Vol. V, 3, 541-550.

Suc, J.-P., Fauquette, S., 2012. Pollen floras, a tool to estimate palaeoaltitude of mountains: the Eastern Pyrenees in the Late Neogene, a case study. Palaeogeography, Palaeoclimatology, Palaeoecology 321-322, 41-54.

Suc, J.-P., Zagwijn, W.H., 1983. Plio-Pleistocene correlations between the northwestern Mediterranean region and northwestern Europe according to recent biostratigraphic and paleoclimatic data. Boreas 12, 153-166.

Suc, J.-P., Bertini, A., Combourieu-Nebout, N., Diniz, F., Leroy, S., Russo-Ermolli E., Zheng, Z., Bessais, E., Ferrier, J., 1995a. Structure of West Mediterranean and climate since 5.3 Ma. Acta zoologica cracovia 38, 3-16.

Suc, J.-P., Clauzon, G., Bessedik, M., Leroy, S., Zheng, Z., Drivaliari, A., Roiron, P., Ambert, P., Martinell, J., Doménech, R., Matias, I., Julià, R., Anglada, R., 1992. Neogene and Lower Pleistocene in Southern France and Northeastern Spain. Mediterranean environments and climate. Cahiers de Micropaleontologie 7, 1-2, 165-186.

Suc, J.-P., Diniz, F., Leroy, S., Poumot, C., Bertini, A., Dupont, L., Clet, M., Bessais, E., Zheng, Z., Fauquette, S., Ferrier, J., 1995b. Zanclean ( Brunssumian) to early Piacenzian ( early-middle Reuverian) climate from $4^{\circ}$ to $54^{\circ}$ north latitude (West Africa, West Europe and West Mediterranean areas). Mededelingen Rijks Geologische Dienst 52, 43 56.

Suc, J.-P., Fauquette, S., Bessedik, M., Bertini, A., Zheng, Z., Clauzon, G., Suballyova, D., Diniz, F., Quézel, P., Feddi, N., Clet, M., Bessais, E., Bachiri Taoufiq, N., Meon, H., Combourieu-Nebout, N., 1999. Neogene vegetation changes in West European and West circum-Mediterranean areas, in: Agustí, J., Rook, L., Andrews, P. (Eds.), The Evolution of Neogene Terrestial Ecosystems in Europe. Cambridge University Press, pp. 378-388.

Sue, C., Delacou, B., Champagnac, J.-D., Allanic, C., Tricart, P., Burkhard, M., 2007. Extensional neotectonics around the bend of the Western/Central Alpes: an overview. International Journal of Earth Sciences 96, 1101-1129.

Tricart, P., Lardeaux, J.-M., Schwartz, S., Sue, C., 2006. The late extension in the inner western Alps: a synthesis along the south-Pelvoux transect. Bulletin de la Société Géologique de France 177, 299-310.

Tricart, P., van der Beek, P., Schwartz, S., Labrin, E., 2007. Diachronous late-stage exhumation across the western Alpine arc: constraints from apatite fission-track thermochronology between the Pelvoux and Dora-Maira Massifs. Journal of the Geological Society London 164, 163-174.

Vernon, A.J., van der Beek, P.A., Sinclair, H.D., Rahn, M.K., 2008. Increase in Late Cenozoic denudation of the European Alps confirmed by analysis of a fission track thermochronology database. Earth Planet. Sci. Lett. 270, 316-329.

Vernon, A.J., van der Beek, P.A., Sinclair, H., 2009. Spatial correlation between long-term exhumation rates and present-day forcing parameters in the western European Alps. Geology 37, 859-862.

von Blanckenburg, F., Davies, J. H., 1995. Slab breakoff; a model for syncollisional magmatism and tectonics in the Alps. Tectonics 14, 120-131. 
Wang, C.W., 1961. The forests of China with a survey of grassland and desert vegetation. Maria Moors Cabot Foundation, 5, Harvard University, Cambridge, Massachusetts.

Whipple, K.X., 2009. The influence of climate on the tectonic evolution of mountain belts. Nature Geoscience 2, 97-104.

Whipple, K.X., Meade, B.J., 2006. Orogen response to changes in climatic and tectonic forcing. Earth and Planetary Science Letters 243, 218-228.

Willett, S., 1999. Orogeny and orography: The effects of erosion on the structure of mountain belts. Journal of Geophysical Research 104, 28,957-28,981.

Willett, S., Beaumont, C., Fullsack, P., 1993. Mechanical model for the tectonics of doubly vergent compressional orogens. Geology 21, 371-374.

Zachos, J. C., Dickens, G. R., Zeebe, R. E., 2008. An early Cenozoic perspective on greenhouse warming and carbon-cycle dynamics. Nature 451, 279-283.

Zachos, J., Pagani, M., Sloan, L., Thomas, E., Billups, K., 2001. Trends, rhythms, and aberrations in global climate 65 Ma to Present. Science 292, 686-693.

Zarki-Jakni, B., van der Beek, P., Poupeau, G., Sosson, M., Labrin, E., Rossi, P., Ferrandini, J., 2004. Cenozoic denudation of Corsica in response to Ligurian and Tyrrhenian extension: Results from apatite fission track thermochronology. Tectonics 23, TC1003, 1010.1029/2003TC001535.

Zheng, Z., 1990. Végétations et climats néogènes des Alpes maritimes franco-italiennes d'après les données de l'analyse palynologique. Paléobiologie Continentale 17, 217-244.

Zheng, Z., Cravatte, J., 1986. Etude palynologique du Pliocène de la Côte d'Azur (France) et du littoral ligure (Italie). Geobios 19, 6, 815-823. 


\section{Figure captions}
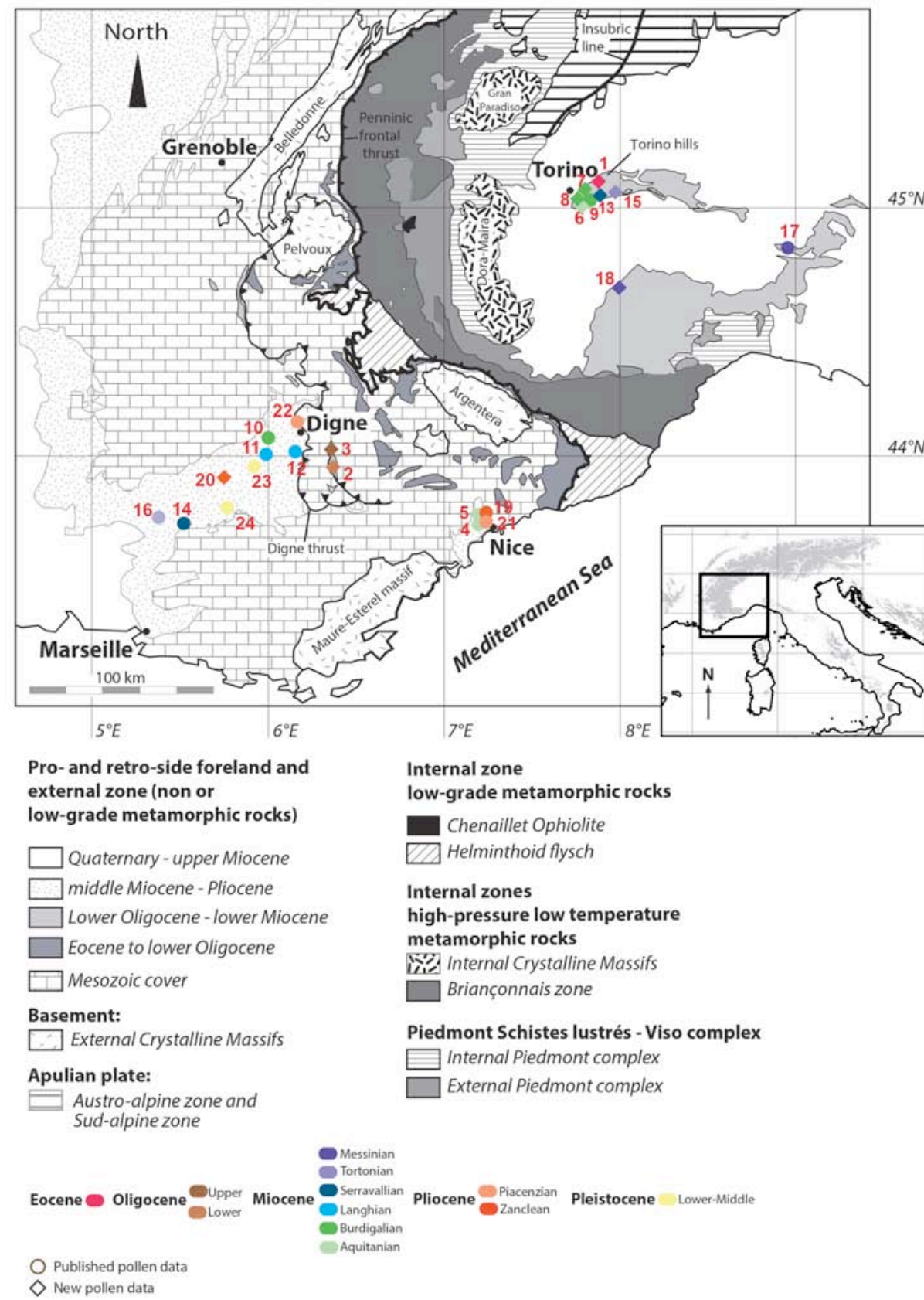

Fig. 1. Simplified geological map of the western Alps (modified from Jourdan et al., 2012) showing the location of the Paleogene to Neogene pollen sites.

Pollen sites are numbered according to stratigraphic age: 1, Gassino Torinese; 2, Saint-Lions; 3, Gambi; 4, Le Gourg; 5, Carros; 6, Tetti Civera 1; 7, Tetti Civera 2; 8, Tetti Civera 3; 9, Rio Civera; 10, La Rosée; 11, Les Mées 1 (borehole); 12, Châteauredon; 13, Pavarolo; 14, La Motte d'Aigues; 15, Borelli; 16, Vaugines; 17, Torre Sterpi; 18, Sioneri; 19, Saint-Martin du Var; 20, Villeneuve; 21, Saint-Isidore; 22, Le Rochassas; 23, Les Mées-Périgoite; 24, Oraison-Flour. New pollen data are indicated by a diamond and published pollen data by a circle. 

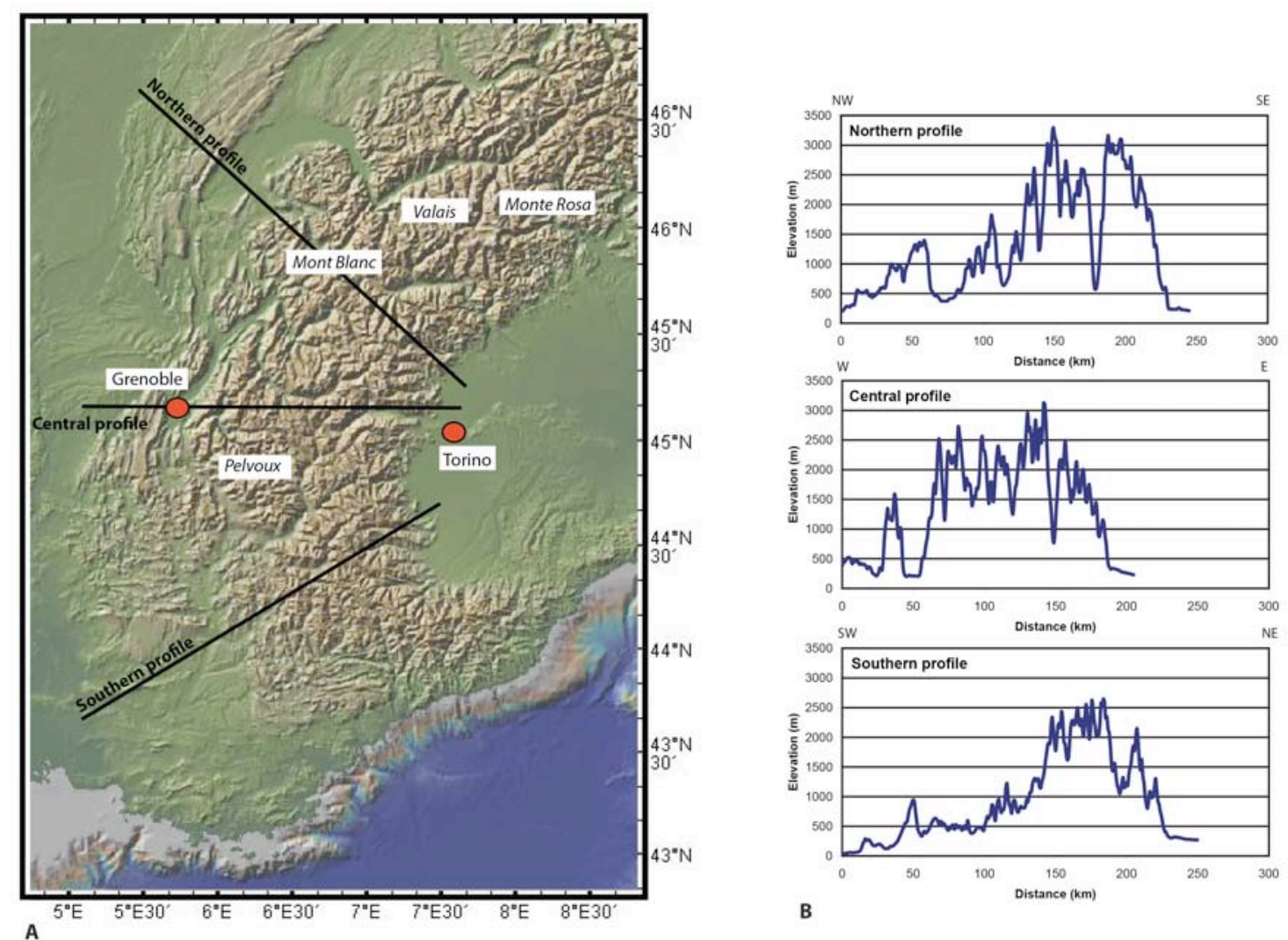

Fig. 2. A) Topographic map of the western Alps with the location of the areas with mountain peaks over $>4000$ m elevation (Mont Blanc, Valais, Monte Rosa, and Pelvoux) and B) three east-west profiles in the northern, central and southern parts of the western Alps. Particularly the northern and southern profiles show the asymmetric topography of the Western Alps with a steep eastern flank and a gentler western flank. The map was made with the GeoMap App (http://www.geomapapp.org), using the Global Multi-Resolution Topography (GMRT) basemap (Ryan et al., 2009).

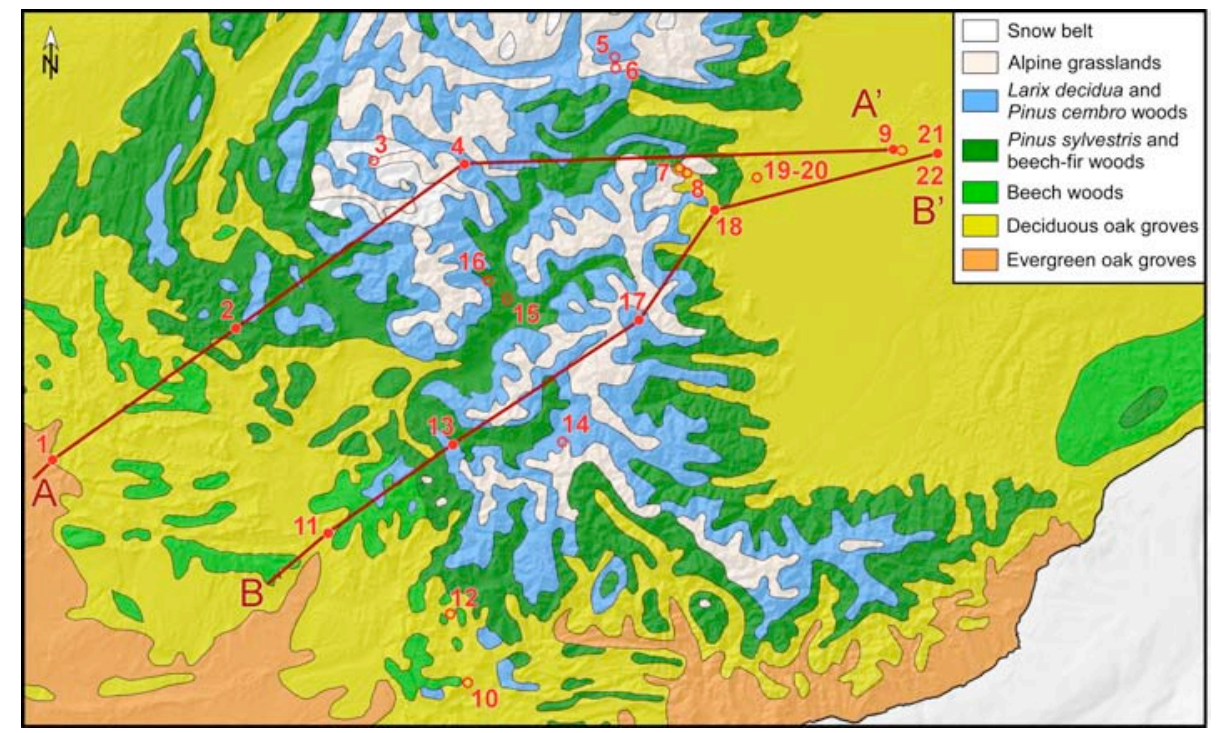

Fig. 3. Simplified vegetation map of the southwestern Alps (from Noirfalise et al., 1987) and position of the two transects along which modern pollen data were collected (localities on the transects are indicated by dots, localities out of the transects by circles). The relief of the map was added using the GeoMap App (http://www.geomapapp.org) (Ryan et al., 2009). See Supplementary Table 1 for details on the localities. 


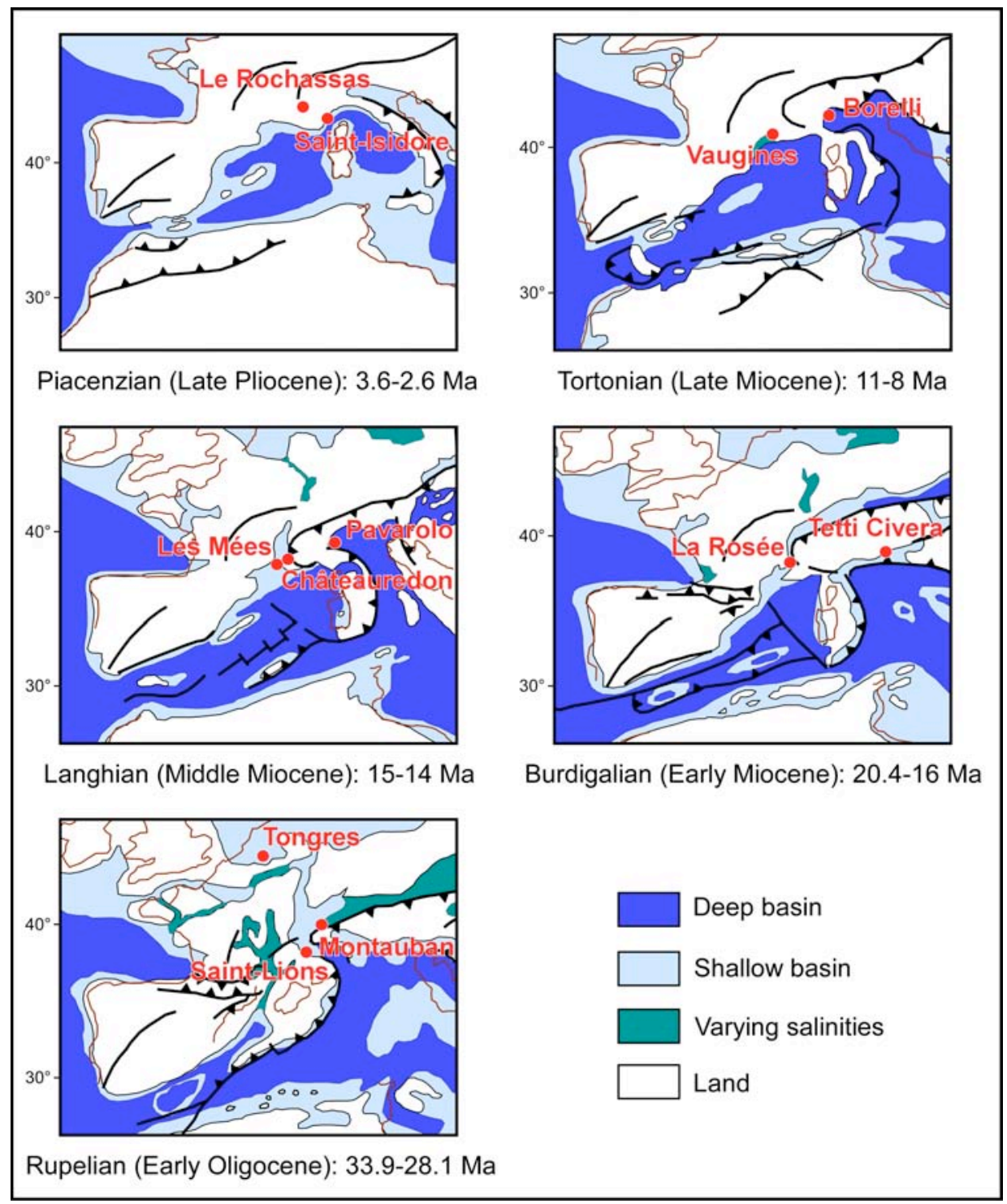

Fig. 4. Palaeogeographic maps (from Meulenkamp and Sissingh, 2003) with the position of the concerned sites for the late Rupelian, Burdigalian, Langhian, Tortonian and Piacenzian. 


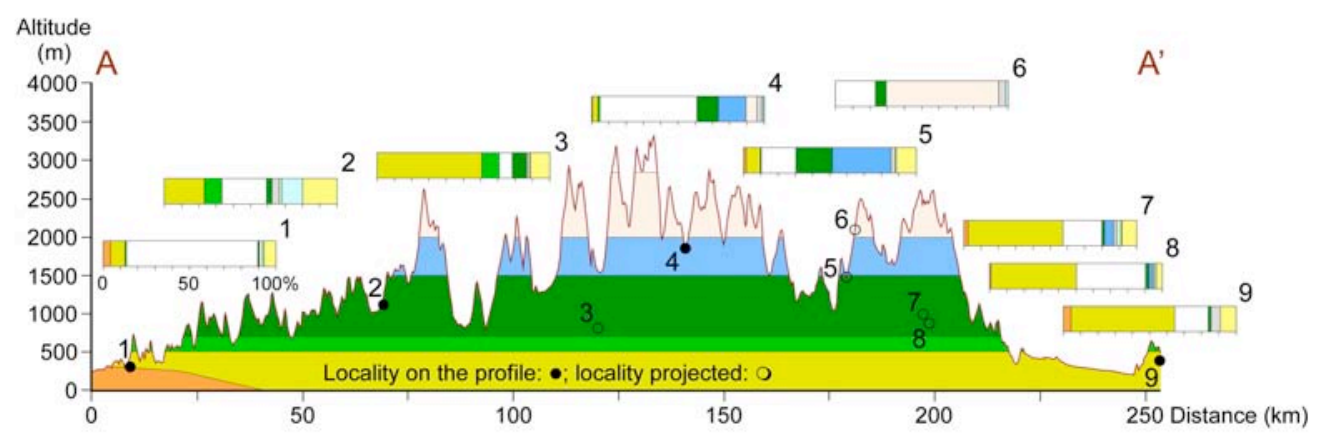

\begin{tabular}{ll}
\hline Vegetation belts: & $\square$ Snow belt \\
$\square$ Beech woods & $\square$ Alpine grasslands \\
$\square$ Deciduous oak groves & $\square$ Larix decidua and Pinus cembro woods \\
$\square$ Evergreen oak groves & Pinus sylvestris and beech-fir woods \\
Pollen groups: & $\square$ Herbs of Alpine grasslands \\
$\square$ Beech & $\square$ Plants without signification \\
$\square$ Deciduous warm-temperate plants \\
$\square$ Mediterranean xerophytes \\
$\square$ Pir and spruce
\end{tabular}

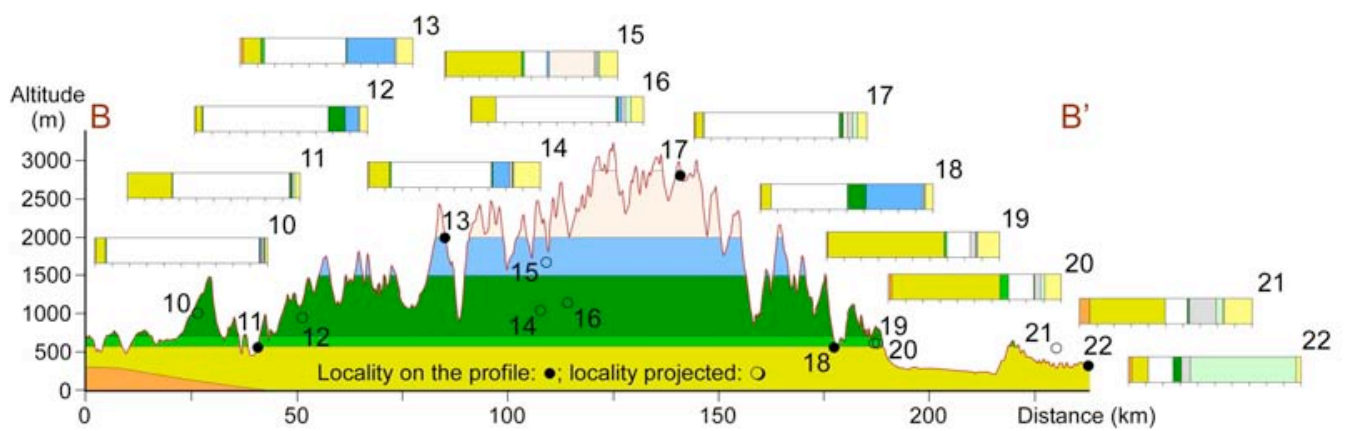

Fig. 5. Topography along the two transects of Fig.3, position of the different vegetation belts (from Noirfalise et al., 1987; Ozenda, 2002) and relative proportions of pollen groups in the modern samples.

Pollen localities are:

Transect AA': 1, Nyons; 2, Luz la Croix haute; 3, Le Freney; 4, Col du Lautaret; 5 - 6, Mont Cenis; 7, Pinerolese (Lago Villaretto di Roure); 8, Pinerolese (Balma di Roure); 9, Baldissero Torinese (Val Samfrà).

Transect BB': 10, Taulanne; 11, Clumanc; 12, Sisteron; 13, Saint-Léger; 14, Lac de Séguret; 15, Fournel; 16, Roche de Rame; 17, Agnel; 18, Inverso Pinasca; 19 - 20, Cappella della Colletta di Cumiana; 21 Baldissero Torinese; 22, Moncucco Torinese. 


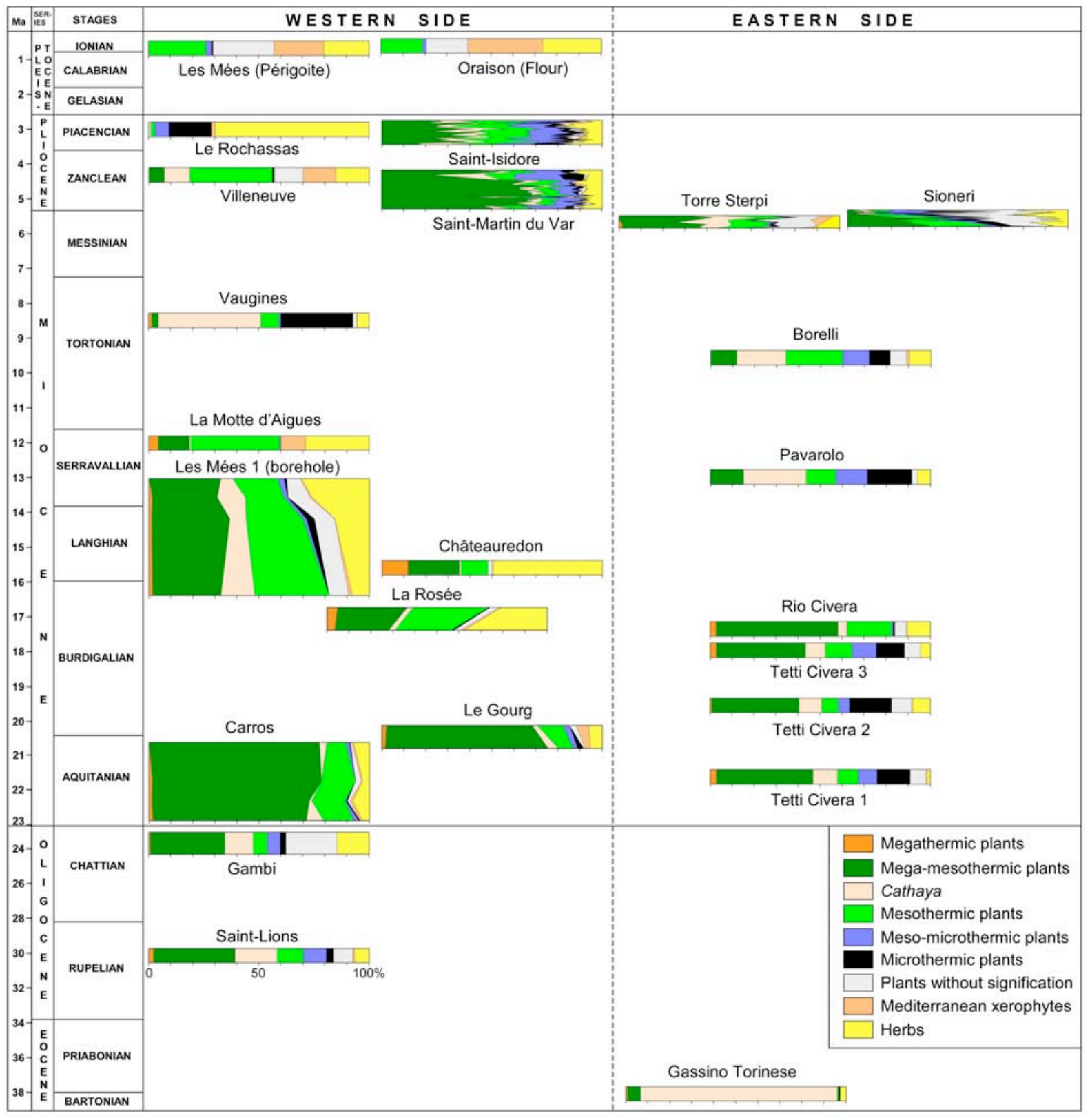

Fig. 6. Synthetic pollen diagrams for the Late Eocene to Pleistocene samples and their position in a chronostratigraphic frame (note the change of timescale at the Paleogene/Neogene boundary). Taxa have been arranged into thirteen different groups based on ecological criteria in order to visualize the main changes in the palaeo-vegetation cover at different altitudinal belts. Some groups are constituted according to thermic requirements of taxa with respect to the Nix (1982) classification based on the mean annual temperature (MAT): megathermic (tropical): $\mathrm{MAT}>24^{\circ} \mathrm{C}$; mega-mesothermic (subtropical): $20^{\circ} \mathrm{C}<\mathrm{MAT}<24^{\circ} \mathrm{C}$; mesothermic (warm-temperate): $14^{\circ} \mathrm{C}<\mathrm{MAT}<20^{\circ} \mathrm{C}$; meso-microthermic (cool-temperate): $12^{\circ} \mathrm{C}<\mathrm{MAT}<14^{\circ} \mathrm{C}$; microthermic (boreal): $\mathrm{MAT}<12^{\circ} \mathrm{C}$. 

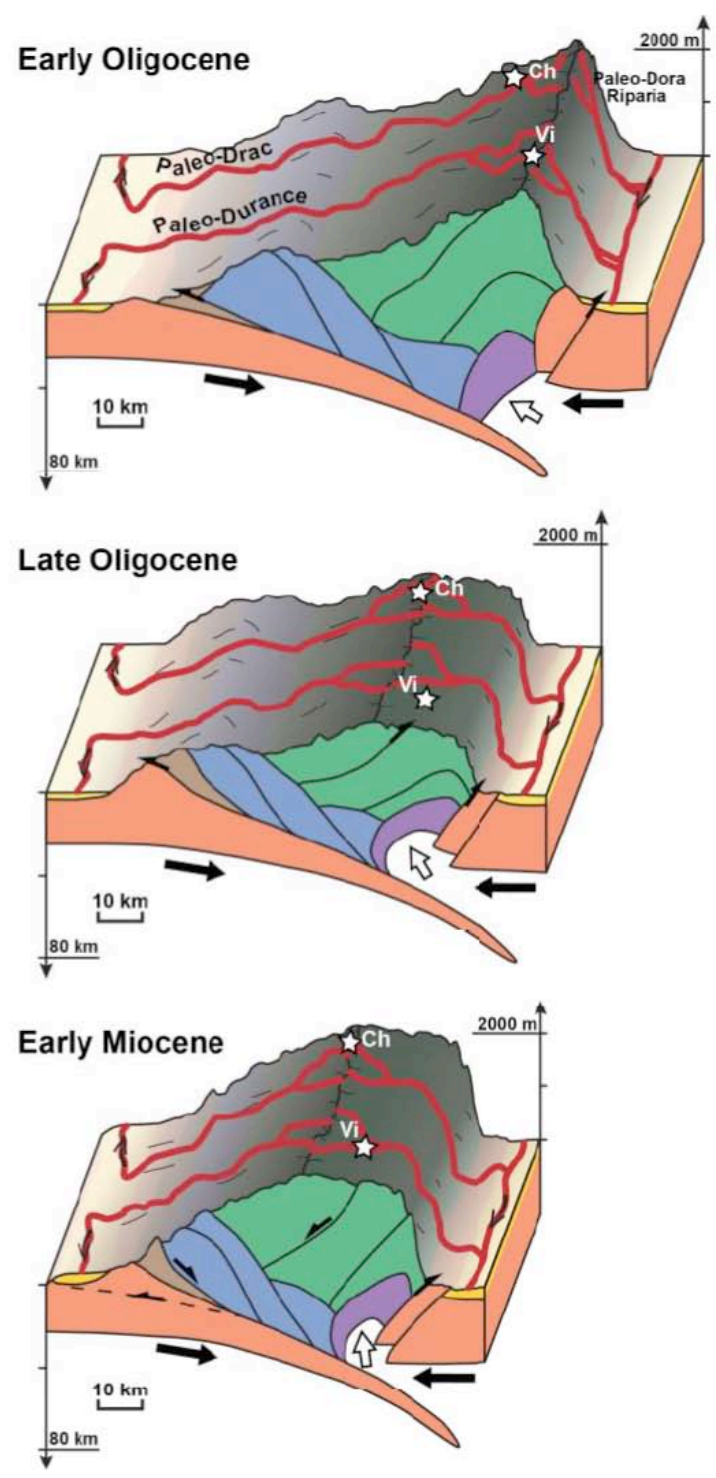

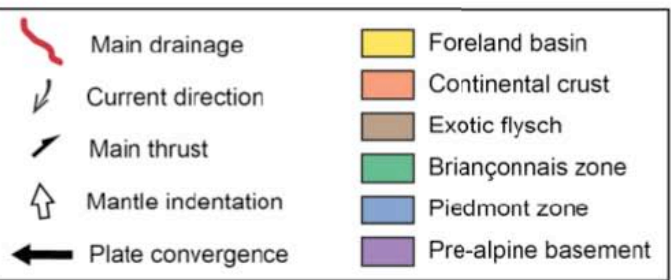

Fig. 7. Schematic reconstruction of the topographic and drainage evolution of the southwestern Alps from Early Oligocene to Early Miocene, showing the palaeo-Durance and the palaeo-Drac rivers draining the western flank of the main divide and the palaeo-DoraRiparia draining the eastern flank. 


\begin{tabular}{|c|c|c|c|c|c|c|c|c|}
\hline & Sites & Age & $\begin{array}{l}\text { Depositional } \\
\text { environment }\end{array}$ & $\begin{array}{c}\text { Palaeo-latitude } \\
\left({ }^{\circ} \mathrm{N}\right) \\
\end{array}$ & $\begin{array}{c}\text { MAT }\left({ }^{\circ} \mathbf{C}\right) \\
\text { Min-MLV - max }\end{array}$ & $\begin{array}{c}\text { Shift in } \\
\text { altitude }(m)\end{array}$ & $\begin{array}{l}\text { Microthermic trees in pollen } \\
\text { records }\end{array}$ & $\begin{array}{c}\text { Palaeoaltitude of } \\
\text { nearby massifs }\end{array}$ \\
\hline \multirow{12}{*}{$\begin{array}{c}\text { French } \\
\text { slope }\end{array}$} & 21 Saint-Isidore & Early Piacenzan & Marine, deltaic & Modern & $14.8-17-18.2$ & $+265+640+860$ & Abies, Picea, Cathaya, Cedrus & $2040 \mathrm{~m}(1665 / 2260)$ \\
\hline & $\begin{array}{c}20 \begin{array}{l}\text { Villeneuve Pigeonnier } \\
\text { de l'Ange }\end{array} \\
\end{array}$ & Middle Zanclean & Marine, deltaic & Modern & $11.9-16.5-24.7$ & & Cathaya & 950 to $1800 \mathrm{~m}$ \\
\hline & 19 Saint-Martin du Var & $\begin{array}{l}\text { Latest Messinian to } \\
\text { Early Zanclean }\end{array}$ & Marine, deltaic & Modern & $15-\mathbf{1 6 . 5}-18.6$ & $+300+541+930$ & Abies, Picea, Cathaya, Cedrus & $1940 \mathrm{~m}(1700 / 2330)$ \\
\hline & 16 Vaugines & Late Tortonian & Palustrine & 41 & $10-\mathbf{1 6 . 8}-22.8$ & $-1000+270+1460$ & Abies, Picea, Cathaya & $1670 \mathrm{~m}(400 / 2860)$ \\
\hline & 14 La Motte d'Aigues & Latest Serravallian & $\begin{array}{c}\text { Marine, } \\
\text { embayment }\end{array}$ & 38 & $16-\mathbf{- 1 7 . 9}-22.8$ & & Very rare Cathaya & Low altitude \\
\hline & 12 Châteauredon & Early Langhian & $\begin{array}{c}\text { Marine, } \\
\text { embayment }\end{array}$ & 38.2 & $17.4-19.7-22.8$ & & Very rare Cathaya & Low altitude \\
\hline & 11 Les Mées (borehole) & $\begin{array}{l}\text { Latest Burdigalian to } \\
\text { early Serravallian }\end{array}$ & $\begin{array}{c}\text { Marine, } \\
\text { embayment }\end{array}$ & 38 & $17-\mathbf{- 1 8 . 8}-21.8$ & & $\begin{array}{c}\text { Cathaya, very rare Abies, Picea, } \\
\text { Cedrus }\end{array}$ & Low altitude \\
\hline & 10 La Rosée & Late Burdigalian & $\begin{array}{c}\text { Marine, } \\
\text { embayment }\end{array}$ & & $15-\mathbf{2 0}-24.5$ & & $\begin{array}{c}\text { Less than } 1 \% \text { of Picea, no Abies, } \\
\text { few Cathaya }\end{array}$ & 950 to $1800 \mathrm{~m}$ \\
\hline & 4 Le Gourg & Latest Aquitanian & $\begin{array}{c}\text { Marine, } \\
\text { embayment }\end{array}$ & 37.2 & $16.8-\mathbf{1 9 . 4}-24.7$ & & $\begin{array}{l}\text { Less than } 1 \% \text { of Picea and Abies, } \\
\text { few Cathaya and Cedrus }\end{array}$ & 950 to $1800 \mathrm{~m}$ \\
\hline & 5 Carros & Aquitanian & $\begin{array}{c}\text { Marine, } \\
\text { embayment }\end{array}$ & 37.2 & $16.8-\mathbf{1 9 . 4}-24.7$ & & $\begin{array}{c}\text { Cathaya, Cedrus, very rare Picea } \\
\text { and Abies }\end{array}$ & 950 to $1800 \mathrm{~m}$ \\
\hline & 3 Gambi & Chattian & Marine, deltaic & 38 & $15.6-\mathbf{1 8 . 8}-24.7$ & $-290+\mathbf{3 4 0}+1500$ & $\begin{array}{c}\text { Cathaya, Picea, Cedrus, very rare } \\
\text { Abies }\end{array}$ & $1740 \mathrm{~m}(1110 / 2900)$ \\
\hline & 2 Saint-Lions & Rupelian & Marine, deltaic & 38 & $15.6-19.6-24.7$ & $-290+500+1500$ & Cathaya, Cedrus, Picea & $1900 \mathrm{~m}(1110 / 2900)$ \\
\hline \multirow{9}{*}{$\begin{array}{c}\text { Italian } \\
\text { slope }\end{array}$} & 17 Torre Sterpi & Latest Messinian & Lagoonal & 41.5 & $15.6-\mathbf{1 7 . 6}-20$ & $+90+\mathbf{4 8 5}+960$ & $\begin{array}{c}\text { Mostly Cathaya, Cedrus, Picea, } \\
\text { Abies }\end{array}$ & $1785 \mathrm{~m}(1400 / 2260)$ \\
\hline & 18 Sioneri & Latest Messinian & Lagoonal & 41.5 & $15.6-\mathbf{1 7 . 7}-22.8$ & $+90+\mathbf{5 0 0}+960$ & $\begin{array}{l}\text { Mostly Picea, Abies, Cedrus, } \\
\text { Cathaya }\end{array}$ & $1800 \mathrm{~m}(1390 / 2800)$ \\
\hline & 15 Borelli & Middle Tortonian & $\begin{array}{c}\text { Marine, } \\
\text { embayment }\end{array}$ & 42.4 & $15.5-\mathbf{1 7 . 8}-22.8$ & $+165+\mathbf{6 2 5}+1600$ & Abies, Picea, Cathaya, Cedrus & $1925 \mathrm{~m}(1465 / 2900)$ \\
\hline & 13 Pavarolo & Serravallian & $\begin{array}{c}\text { Marine, } \\
\text { embayment }\end{array}$ & 40 & $17-19-24.7$ & $+200+600+1700$ & Abies, Picea, Cathaya, Cedrus & $1900 \mathrm{~m}(1500 / 3000)$ \\
\hline & 9 Rio Civera & Late Burdigalian & $\begin{array}{c}\text { Marine, } \\
\text { embayment }\end{array}$ & 39.5 & $15.7-\mathbf{1 8 . 7}-21.7$ & $-110+\mathbf{4 8 0}+1080$ & $\begin{array}{c}\text { Very rare Abies and Cedrus, } \\
\text { mostly Cathaya }\end{array}$ & $1780 \mathrm{~m}(1200 / 2380)$ \\
\hline & 8 Tetti Civera 3 & Middle Burdigalian & $\begin{array}{c}\text { Marine, } \\
\text { embayment }\end{array}$ & 39.5 & $15.6-\mathbf{1 9}-24.7$ & $-130+\mathbf{5 4 0}+1650$ & \multirow{3}{*}{ Abies, Picea, Cathaya, Cedrus } & $1840 \mathrm{~m}(1170 / 2950)$ \\
\hline & 7 Tetti Civera 2 & Early Burdigalian & $\begin{array}{c}\text { Marine, } \\
\text { embayment }\end{array}$ & 39.5 & $15.6-\mathbf{1 8 . 8}-24.7$ & $-130+\mathbf{5 0 0}+1650$ & & $1800 \mathrm{~m}(1170 / 2950)$ \\
\hline & 6 Tetti Civera 1 & Aquitanian & $\begin{array}{c}\text { Marine, } \\
\text { embayment }\end{array}$ & 38.5 & $16.8-\mathbf{1 8 . 7}-21.6$ & $+0+\mathbf{3 8 0}+950$ & & $1680 \mathrm{~m}(1300 / 2250)$ \\
\hline & 1 Gassino Torinese & Priabonian & $\begin{array}{l}\text { Marine, } \\
\text { embayment }\end{array}$ & 36 & $15-\mathbf{1 9 . 2}-24.7$ & & Cathaya, very rare Picea & 950 to $1800 \mathrm{~m}$ \\
\hline
\end{tabular}

Table 1. Results of the palaeo-elevation estimates for marine sediment sites. For each site we report the age and depositional environment of the sediments, the palaeolatitude based on the palaeogeographic maps of Meulenkamp and Sissingh (2003), the estimated mean annual temperature from pollen data (minimum, Most Likely Value, maximum MAT), the shift in altitude of the vegetation belts due to the differences in temperature with respect to the present-day, the most probable palaeo-elevations of the nearby massifs based on the Most Likely Values of MAT and, in brackets, ranges of palaeo-elevations based on the minimum and maximum MAT.

\begin{tabular}{|c|c|c|c|c|c|c|}
\hline $\begin{array}{l}\text { Non-marine } \\
\text { sediment sites }\end{array}$ & $\begin{array}{l}\text { Modern } \\
\text { elevation (m) }\end{array}$ & Age & $\begin{array}{l}\text { Depositional } \\
\text { environment }\end{array}$ & $\begin{array}{c}\text { MLV of MAT } \\
\left({ }^{\circ} \mathbf{C}\right)\end{array}$ & $\begin{array}{c}\text { Contemporaneous flora } \\
\text { living in lowlands }\end{array}$ & $\begin{array}{c}\text { Paleoaltitude of the } \\
\text { sites }\end{array}$ \\
\hline $\begin{array}{l}24 \text { Oraison - } \\
\text { Flour }\end{array}$ & 408 & $\begin{array}{l}\text { Early } \\
\text { Pleistocene }\end{array}$ & Fluvial loams & 14.8 & \multirow{2}{*}{$\begin{array}{l}\text { Semaforo (Southern Italy, } \\
\text { Fauquette and Combourieu- } \\
\text { Nebout, 2013) }\end{array}$} & $420 \mathrm{~m}$ \\
\hline $\begin{array}{l}23 \text { Les Mées - } \\
\text { Périgoite }\end{array}$ & 522 & $\begin{array}{l}\text { Early } \\
\text { Pleistocene }\end{array}$ & Fluvial loams & 15.2 & & $330 \mathrm{~m}$ \\
\hline $\begin{array}{l}22 \mathrm{Le} \\
\text { Rochassas }\end{array}$ & 820 & Piacenzian & Palustrine & 12 & $\begin{array}{l}\text { St Isidore (Southern France, } \\
\text { Zheng and Cravatte, 1986) }\end{array}$ & $890 \mathrm{~m}$ \\
\hline 16 Vaugines & 430 & Tortonian & Palustrine & 16.8 & Mirabel (Naud and Suc, 1975) & $\sim 0$ \\
\hline
\end{tabular}

Table 2. Results of the palaeo-elevation estimates for non-marine sediment sites. For each site we report the modern elevation, the age and depositional environment of the sediments, the Most Likely Value of MAT, the contemporaneous flora living in lowlands used for the comparison and the palaeo-elevation of the site. 


\section{Supplementary material:}

A.

\begin{tabular}{|c|l|l|r|r|}
\hline $\begin{array}{c}\text { Number on } \\
\text { Fig. } 3\end{array}$ & Site & N Latitude & E Longitude & $\begin{array}{c}\text { Altitude } \\
\text { (m) }\end{array}$ \\
\hline 1 & Nyons & $44^{\circ} 22^{\prime}$ & $5^{\circ} 05^{\prime}$ & 300 \\
\hline 2 & Luz la Croix haute & $44^{\circ} 39^{\prime}$ & $5^{\circ} 42^{\prime}$ & 1100 \\
\hline 3 & Le Freney & $45^{\circ} 02^{\prime}$ & $6^{\circ} 08^{\prime}$ & 800 \\
\hline 4 & Col du Lautaret & $45^{\circ} 02^{\prime}$ & $6^{\circ} 26^{\prime}$ & 1850 \\
\hline 5 & Mont Cenis (lower) & $45^{\circ} 16^{\prime}$ & $6^{\circ} 54^{\prime}$ & 1479 \\
\hline 6 & Mont Cenis (upper) & $45^{\circ} 15^{\prime}$ & $6^{\circ} 54^{\prime}$ & 2083 \\
\hline 7 & Pinerolese (Lago Villaretto du Route) & $45^{\circ} 01^{\prime} 05.52^{\prime \prime}$ & $7^{\circ} 06^{\prime} 23.44^{\prime \prime}$ & 980 \\
\hline 8 & Pinerolese (Balma di Roure) & $45^{\circ} 00^{\prime} 17.90^{\prime \prime}$ & $7^{\circ} 07^{\prime} 31.54^{\prime \prime}$ & 890 \\
\hline 9 & Baldissero Torinese (Val Samfrà) & $45^{\circ} 04^{\prime} 19.27^{\prime \prime}$ & $7^{\circ} 48^{\prime} 59.79^{\prime \prime}$ & 383 \\
\hline 10 & Taulanne & $43^{\circ} 52^{\prime} 35.40^{\prime \prime}$ & $6^{\circ} 26^{\prime} 32.40^{\prime \prime}$ & 995 \\
\hline 11 & Clumanc & $44^{\circ} 01^{\prime} 38.20^{\prime \prime}$ & $6^{\circ} 23^{\prime} 06.00^{\prime \prime}$ & 940 \\
\hline 12 & Sisteron & $44^{\circ} 11^{\prime}$ & $5^{\circ} 57^{\prime}$ & 540 \\
\hline 13 & Saint-Léger & $44^{\circ} 24^{\prime}$ & $6^{\circ} 24^{\prime}$ & 2000 \\
\hline 14 & Lac de Séguret & $44^{\circ} 25^{\prime}$ & $6^{\circ} 44^{\prime}$ & 1030 \\
\hline 15 & Fournel & $44^{\circ} 46^{\prime} 28.00^{\prime \prime}$ & $6^{\circ} 30^{\prime} 16.80^{\prime \prime}$ & 1680 \\
\hline 16 & Roche de Rame & $44^{\circ} 44^{\prime} 18.60^{\prime \prime}$ & $6^{\circ} 34^{\prime}$ & 1120 \\
\hline 17 & Agnel & $44^{\circ} 41^{\prime} 04.20^{\prime \prime}$ & $6^{\circ} 58^{\prime} 41.20^{\prime \prime}$ & 2800 \\
\hline 18 & Inverso Pinasca & $44^{\circ} 56^{\prime} 25.24^{\prime \prime}$ & $7^{\circ} 13^{\prime} 19.40^{\prime \prime}$ & 560 \\
\hline 19 & Cappella della Colletta du Cumiana & $45^{\circ} 00^{\prime} 23.46^{\prime \prime}$ & $7^{\circ} 21^{\prime} 33.17^{\prime \prime}$ & 612 \\
\hline 20 & Cappella della Colletta du Cumiana & $45^{\circ} 00^{\prime} 25.58^{\prime \prime}$ & $7^{\circ} 21^{\prime} 32.16^{\prime \prime}$ & 605 \\
\hline 21 & Baldissero Torinese & $45^{\circ} 04^{\prime} 22.23^{\prime \prime}$ & $7^{\circ} 48^{\prime} 09.22^{\prime \prime}$ & 537 \\
\hline 22 & Moncucco Torinese & $45^{\circ} 03^{\prime} 50.30^{\prime \prime}$ & $7^{\circ} 56^{\prime} 21.13^{\prime \prime}$ & 315 \\
\hline
\end{tabular}

B.

\begin{tabular}{|c|c|c|c|c|c|}
\hline $\begin{array}{l}\text { Number on } \\
\text { Fig. } 1\end{array}$ & Site & Age and related reference & N Latitude & E Longitude & $\begin{array}{l}\text { Altitude } \\
\text { (m) }\end{array}$ \\
\hline 1 & Gassino Torinese & $\begin{array}{l}\text { Bartonian - Priabonian (Festa et al., } \\
\text { 2011) }\end{array}$ & $45^{\circ} 7^{\prime} 23.90^{\prime \prime}$ & $7^{\circ} 51^{\prime} 35.90^{\prime \prime}$ & 267 \\
\hline 2 & Saint-Lions & Late Rupelian (Grosjean et al., 2012) & $43^{\circ} 58^{\prime} 58.90^{\prime \prime}$ & $6^{\circ} 23^{\prime} 42.70^{\prime \prime}$ & 817 \\
\hline 3 & Gambi (grey molase) & Late Chattian (Grosjean et al., 2012) & $44^{\circ} 01^{\prime} 59^{\prime \prime}$ & $6^{\circ} 22^{\prime} 33.20^{\prime \prime}$ & 855 \\
\hline 4 & Le Gourg & Late Aquitanian (Zheng, 1990) & $43^{\circ} 46^{\prime} 56.03^{\prime \prime}$ & $7^{\circ} 10^{\prime} 22.22^{\prime}$ & 408 \\
\hline 5 & Carros & Aquitanian (Zheng, 1990) & $43^{\circ} 47^{\prime} 54.94^{\prime \prime}$ & $7^{\circ} 11^{\prime} 14.41^{\prime \prime}$ & 315 \\
\hline 6 & Tetti Civera 1 & Aquitanian (Festa et al., 2011) & $45^{\circ} 03^{\prime} 59.60^{\prime \prime}$ & $7^{\circ} 47^{\prime} 28.10^{\prime \prime}$ & 422 \\
\hline 7 & Tetti Civera 2 & Early Burdigalian (Festa et al., 2011) & $45^{\circ} 03^{\prime} 52.20^{\prime \prime}$ & $7^{\circ} 47^{\prime} 31.50^{\prime \prime}$ & 423 \\
\hline 8 & Tetti Civera 3 & $\begin{array}{l}\text { Middle Burdigalian (Festa et al., } \\
\text { 2011) }\end{array}$ & $45^{\circ} 03^{\prime} 41.60^{\prime \prime}$ & $7^{\circ} 47^{\prime} 38.20^{\prime \prime}$ & 431 \\
\hline 9 & Rio Civera & Late Burdigalian (Festa et al., 2011) & $45^{\circ} 03^{\prime} 41.60^{\prime \prime}$ & $7^{\circ} 47^{\prime} 38.20^{\prime \prime}$ & 431 \\
\hline 10 & La Rosée & $\begin{array}{l}\text { Late Burdigalian (Couëffé et al., } \\
\text { 2004) }\end{array}$ & $44^{\circ} 08^{\prime} 51.00^{\prime \prime}$ & $6^{\circ} 00^{\prime} 56.00^{\prime \prime}$ & 500 \\
\hline 11 & Les Mées 1 (borehole) & $\begin{array}{l}\text { Burdigalian to Serravallian (Dubois } \\
\text { and Curnelle, 1978) }\end{array}$ & $44^{\circ} 01^{\prime} 01.07^{\prime \prime}$ & $5^{\circ} 59^{\prime} 14.30^{\prime \prime}$ & $\begin{array}{r}\text { Top well: } \\
730 \\
\end{array}$ \\
\hline 12 & Châteauredon & Early Langhian (Besson et al., 2005) & $44^{\circ} 00^{\prime} 53.00^{\prime \prime}$ & $6^{\circ} 12^{\prime} 48.00^{\prime \prime}$ & 707 \\
\hline 13 & Pavarolo & Early Serravallian (Festa et al., 2011) & $45^{\circ} 03^{\prime} 55.70^{\prime \prime}$ & $7^{\circ} 49^{\prime} 40.50^{\prime \prime}$ & 354 \\
\hline 14 & La Motte d'Aigues & Late Serravallian (Bessedik, 1985) & $43^{\circ} 41^{\prime} 17.30^{\prime \prime}$ & $5^{\circ} 31^{\prime} 45.20^{\prime \prime}$ & 364 \\
\hline 15 & Borelli & Middle Tortonian (Festa et al., 2011) & $45^{\circ} 03^{\prime} 53.50^{\prime \prime}$ & $7^{\circ} 56^{\prime} 28.20^{\prime \prime}$ & 285 \\
\hline 16 & Vaugines & Late Tortonian (Bessedik, 1985) & $43^{\circ} 46^{\prime} 55.98^{\prime \prime}$ & $5^{\circ} 24^{\prime} 37.38^{\prime \prime}$ & 430 \\
\hline 17 & Torre Sterpi & $\begin{array}{l}\text { Latest Messinian (Corselli and } \\
\text { Grecchi, 1984) }\end{array}$ & $44^{\circ} 48^{\prime} 14.90^{\prime \prime}$ & $8^{\circ} 53^{\prime} 37.05^{\prime \prime}$ & 223 \\
\hline 18 & Sioneri & $\begin{array}{l}\text { Latest Messinian (Bertini and } \\
\text { Martinetto, 2008) }\end{array}$ & $44^{\circ} 44^{\prime} 18.97^{\prime \prime}$ & $7^{\circ} 59^{\prime} 59.96^{\prime \prime}$ & 225 \\
\hline 19 & Saint-Martin du Var & $\begin{array}{l}\text { Early Zanclean (Zheng and Cravatte, } \\
1986 \text { ) }\end{array}$ & $43^{\circ} 49^{\prime} 13.83^{\prime \prime}$ & $7^{\circ} 11^{\prime} 39.47^{\prime \prime}$ & 129 \\
\hline 20 & Villeneuve & Zanclean (Aguilar et al., 1982) & $43^{\circ} 54^{\prime} 01.90^{\prime \prime}$ & $5^{\circ} 51^{\prime} 45.40^{\prime \prime}$ & 475 \\
\hline 21 & Saint-Isidore & $\begin{array}{l}\text { Early Piacenzian (Zheng and Cravatte, } \\
\text { 1986) }\end{array}$ & $43^{\circ} 42^{\prime} 29.52^{\prime \prime}$ & $7^{\circ} 11^{\prime} 23.96^{\prime \prime}$ & 136 \\
\hline 22 & Le Rochassas & Piacenzian (Hippolyte et al., 2011) & $44^{\circ} 07^{\prime} 00.57^{\prime \prime}$ & $6^{\circ} 15^{\prime} 43.32^{\prime \prime}$ & 820 \\
\hline 23 & Les Mées (Périgoite) & Ionian (Dubar, 1979) & $43^{\circ} 58^{\prime} 48.33^{\prime \prime}$ & $5^{\circ} 57^{\prime} 38.11^{\prime \prime}$ & 522 \\
\hline 24 & Oraison (Flour) & Ionian (Dubar, 1979) & $43^{\circ} 50^{\prime} 13.30^{\prime \prime}$ & $5.52 ' 23.00 \prime \prime$ & 408 \\
\hline
\end{tabular}

Supplementary Table 1. Location of pollen sites. A) Modern pollen records (numbers of the sites correspond to those on figure 3); B) Fossil pollen records (numbers of the sites correspond to those on Figure 1). 


\begin{tabular}{|c|c|c|}
\hline & $\begin{array}{l}\text { TONGRES } \\
\text { (8 cumulative samples) }\end{array}$ & $\begin{array}{l}\text { MONTAUBAN } \\
\text { (1 sample) }\end{array}$ \\
\hline Pinaceae (Pinus, Abies, Cedrus, Cathaya) & 3410 & \\
\hline Pinus & & 448 \\
\hline Abies & & 5 \\
\hline Picea & & 6 \\
\hline Cathaya & & 24 \\
\hline Taxodiaceae (Taxodium-type mostly) & 97 & 76 \\
\hline Ephedra & 53 & 1 \\
\hline Cupressaceae & & 11 \\
\hline Mastixia (Cornaceae) & 23 & \\
\hline Theaceae (Gordonia) & 205 & \\
\hline Arecaceae & 241 & 6 \\
\hline Arecaceae (Calamus) & 32 & \\
\hline Buxus bahamensis-type & & 1 \\
\hline Dipterocarpus & 8 & \\
\hline Cyrillaceae-Clethraceae & 109 & \\
\hline Araliaceae & 820 & \\
\hline Araliaceae (Acanthopanax-Brassaiopsis) & 38 & \\
\hline Juglandaceae & 37 & \\
\hline Engelhardia & 350 & 1 \\
\hline Platycarya & 105 & \\
\hline Carya & 67 & 2 \\
\hline Ericaceae & 95 & \\
\hline Acer & 12 & \\
\hline Anacardiaceae & 10 & \\
\hline Betulaceae & 33 & \\
\hline Corylus & 26 & \\
\hline Betula & 35 & \\
\hline Carpinus & 20 & \\
\hline Alnus & 23 & 1 \\
\hline Ilex & 41 & 1 \\
\hline Salix & 49 & \\
\hline Olea & 268 & \\
\hline Nyssa & 20 & \\
\hline Eleagnaceae - Sapindaceae & 37 & \\
\hline Hamamelidaceae & 85 & \\
\hline Liquidambar & 8 & \\
\hline Hamamelidaceae (Eustigma, Ostrearia, Trichocladus) & 98 & \\
\hline Exbucklandia (Hamamelidaceae) & & 1 \\
\hline Myrtaceae & 21 & \\
\hline Convolvulaceae & 19 & \\
\hline Ouercus & 103 & 2 \\
\hline Castanea-type & 75 & \\
\hline Tilia & 12 & \\
\hline Ulmus & & 1 \\
\hline Ulmus-Zelkova & 57 & \\
\hline Myricaceae & 285 & \\
\hline Rhamnaceae & 19 & \\
\hline Diospyros & 36 & \\
\hline Rubiaceae & 10 & \\
\hline Mussaenda-type (Rubiaceae) & & 1 \\
\hline cf. Randia (Rubiaceae) & & 1 \\
\hline Sapotaceae & 35 & \\
\hline Mimusops (Sapotaceae) & 26 & \\
\hline Reevesia $($ Sterculiaceae) & 15 & \\
\hline Clerodendron (Verbenaceae) & 22 & \\
\hline Cissus & 21 & \\
\hline Amaranthaceae-Chenopodiaceae & 10 & 1 \\
\hline Apiaceae & 80 & \\
\hline Asteraceae Asteroideae & & 2 \\
\hline Artemisia & & 2 \\
\hline Asteraceae Cichorioideae & & 1 \\
\hline Brassicaceae & & 1 \\
\hline Euphorbia & 51 & \\
\hline Thespesia (Malvaceae) & 19 & \\
\hline Plantago & & 1 \\
\hline Poaceae & 58 & 1 \\
\hline liliaceae & 24 & \\
\hline Sparganium & 488 & \\
\hline Aglaoreidia & 212 & \\
\hline Restionaceae & 318 & \\
\hline Oenotheraceae & 22 & \\
\hline Alisma & 19 & \\
\hline Nympheaceae? & 162 & \\
\hline Indeterminate pollen grains & 455 & 4 \\
\hline Mean annual temperature & $17.5^{\circ} \mathrm{C}$ & $19.6^{\circ} \mathrm{C}$ \\
\hline
\end{tabular}

Supplementary Table 2. Rupelian pollen records from Tongres (Roche and Schuler, 1976) and Montauban used to estimate the Oligocene latitudinal temperature gradient. 